\title{
26. CAMPANIAN-MAESTRICHTIAN DEEP-WATER FORAMINIFERS FROM HOLE 543A, DEEP SEA DRILLING PROJECT ${ }^{1}$
}

\author{
Christoph Hemleben and Joachim Troester, Geologisch-Paläontologisches Institut, Universität Tübingen²
}

\begin{abstract}
Foraminiferal assemblages in sediments from Hole 543A suggest that toward the end of the Cretaceous there was an oscillating carbonate compensation depth (CCD) in the western Central Atlantic. Changing assemblages of siliceous agglutinated and calcareous foraminifers reflect the changing depositional environment, from a ridge crest environment during Campanian time to a deep abyssal environment during Maestrichtian time.
\end{abstract}

\section{INTRODUCTION}

Since the beginning of the Glomar Challenger cruises, only a few sites have been drilled at which Cretaceous sediments were deposited at or below the CCD. Drilling during Leg $78 \mathrm{~A}$ at Site 543 recovered Cretaceous sediments containing both agglutinated and calcareous benthic foraminifers. Planktonic foraminifers are almost completely absent. Therefore, samples from Site 543 show some similarities with those from Sites 196 and 198 and (Hole 198A) (Leg 20), 260 and 261 (Leg 27), and 367 and 368 (Leg 41), with respect to agglutinated foraminifers of the deep abyssal environment. Samples from Sites 327 and 330 (Leg 36), 363 and 364 (Leg 40), and 355 and 358 (Leg 39) can be compared with the calcareous benthic foraminifers from Hole 543A. In this study we describe changing fossil assemblages of agglutinated and calcareous benthic foraminifers. Most calcareous species of these assemblages are well known worldwide, and are therefore comparable to those from land outcrops described by, for example, Brotzen (1936) Butt (1981), Cushman and Jarvis (1932), Cushman (1946), Hanzlikova (1972), Hofker (1957), and Sliter (1968). Since the core recovery at Hole 543A was rather poor (11-52\%), some abrupt changes are difficult to explain. Nevertheless, this study confirms several observations by previous DSDP participants, and may provide a link in our understanding of ridge-crest and of deep-water environments below the carbonate compensation depth (CCD).

\section{BENTHIC SUCCESSION}

Site 543 is situated on the Atlantic Plate at a water depth of $5637 \mathrm{~m}$, well below the present CCD (Figs. 1 and 2). Hole 543A was washed continuously to $332 \mathrm{~m}$ below the sediment surface before any cores were taken. Core 2 is stratigraphically equivalent to the deepest sediment cored at Hole 543 (Core 543-34), which contains radiolarians only (Renz, this volume). The oldest sediment recovered in Hole 543A is a reddish, chalky limestone, interlayered with basaltic pillow lavas (Natland et

\footnotetext{
${ }^{1}$ Biju-Duval, B., Moore, J. C., et al., Init. Repts. DSDP, Vol. 78A: Washington (U.S. Govt, Printing Office).

2 Address: Geologisch-Palāontologisches Institut, Sigwartstr. 10, Universităt Tübingen, Federal Republic of Germany.
}

al., this volume), containing few radiolarians and nannofossils; it is lower Campanian, on the evidence of its nannofossils (Bergen, this volume). The overlying sequence of brown and reddish, ferruginous clay is highly bioturbated, but the original sediment laminae are still visible. Most assemblages are optically rather well preserved. SEM (scanning electron microscope) studies and examination of residues reveal heavily dissolved and fragmented specimens.

\section{Section 543A-5-6}

Section 543A-5-6 is alternately reddish and brown, becoming more reddish down the section. Whereas the sediment of Core 5 is Eocene, as determined from its radiolarians, Core 7 contains nannofossils suggesting a Maestrichtian assignment. Samples 543A-5-2, 113-115 cm and 6-1, 53-55 cm contain an agglutinated foraminiferal assemblage of low diversity, made up of compressed white specimens. This assemblage (assemblage 1, Table 1; Table 2) can be characterized by five species: Hyperammina dilatata, Saccammina grzybowskii, Glomospira serpens, Kalamopsis grzybowskii, and Haplophragmoides cf. walteri. All of these are well known from flysch sediments of Upper Cretaceous and Paleogene deposits (Geroch, 1960; Jurkiewicz, 1967). Section 543A-6,CC contains fragments of calcareous foraminifers among agglutinated species.

\section{Core 543A-7}

Reddish to brown ferruginous mudstones with $\mathrm{CaCO}_{3}$ contents of up to about $25 \%$ mark this core. Bioturbation is common; burrows of Planolites, Zoophycos, and Chondrites are distinguishable. However, sedimentary laminae are still visible, in addition to "pancake-shaped fragments embedded in a brecciated, sheared matrix" (see core descriptions in report for Site 543, this volume). Some of these fragments may be the result of drilling disturbance, but others are certainly reworked pieces. The top of Section 7-3 is characterized by a greenish-grey chalk $5 \mathrm{~cm}$ thick.

The fossil assemblage of the upper third of this core consists of a few radiolarians and agglutinated foraminifers indicating abyssal conditions. The middle section of the core (Samples 7-2, 73-75 cm to 7-3, 84-85 cm) contains calcareous foraminifers (juveniles as well as adults) 


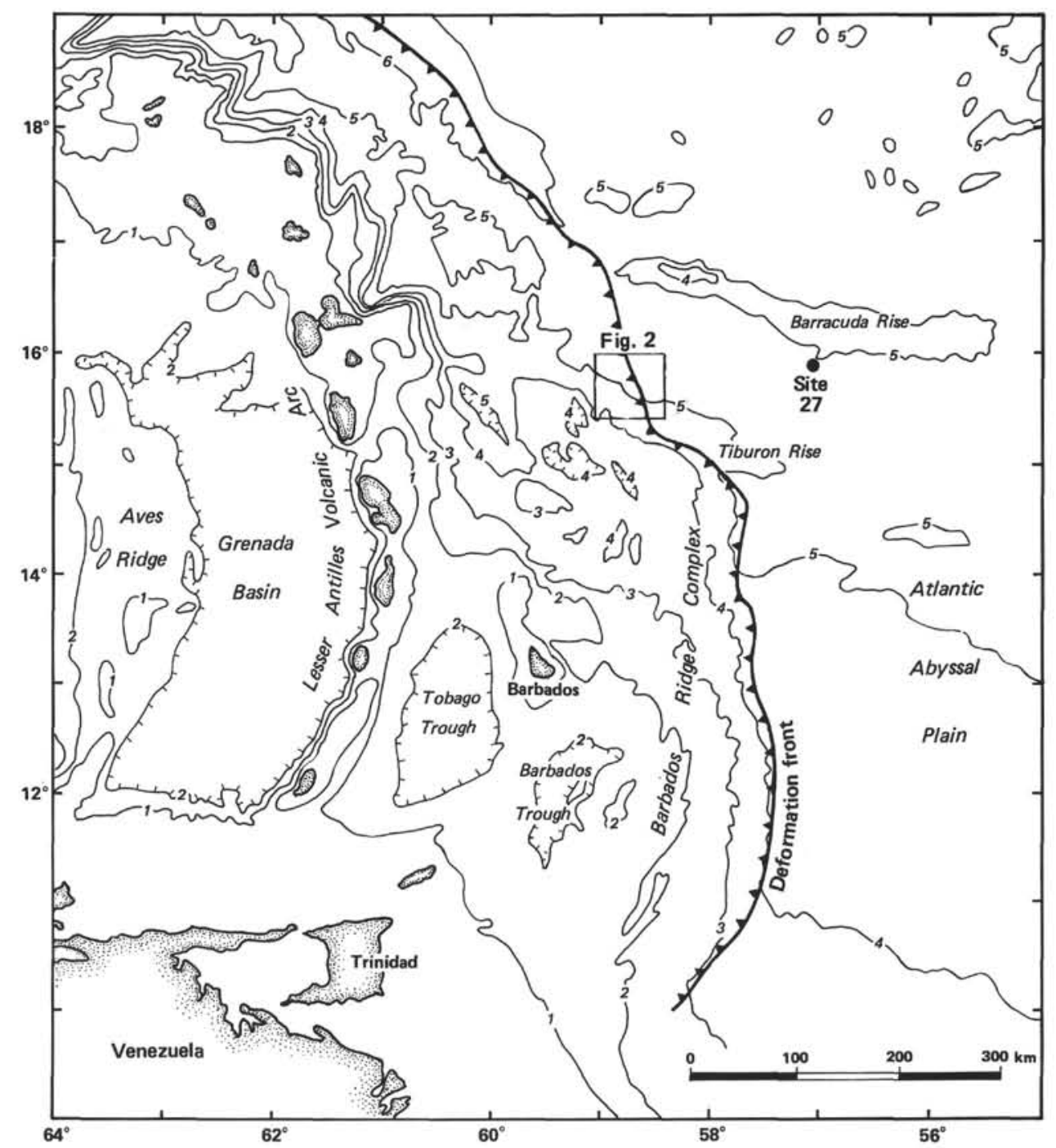

Figure 1. Regional location map. Depth contours in kilometers. Inset shows area of Figure 2. (From Moore et al., 1982.)

and nannofossils. Planktonic foraminifers are absent; not even fragmented pieces were found. Fish teeth and other bone debris occur commonly in all samples. The lower third of Core 7 contains agglutinated foraminifers. Samples $7-1,73-75 \mathrm{~cm}$ and $7-1,146-148 \mathrm{~cm}$ contain a very well preserved agglutinated foraminiferal assemblage. None of the abundant specimens are compressed; but they are even empty. Hyperammina and Rhabdammina are the dominating genera. Glomospira, Tolypammina, Hormosina, Reophax, and Haplophragmoides are abundant as well. The index species Praecystammina globigerinaeformis occurs from Section 6,CC downward throughout the core (assemblage 2, Table 2). Some calcareous fragments are present among the broken agglutinated foraminifers. The number of agglutinated species increases from seven in Section 5,CC to 34 in Sample 7-1, 146-148 cm. A decreasing number of agglutinated species can be observed from Samples 7-2, 73-75 cm downward to Sample 7-2, 84-85 cm. This coincides with the initial dominance of calcareous foraminifers (assemblages 2 and 3). Among the arenaceous species, however, Rhabdammina and Hyperammina are still dominant. About $40 \%$ of the specimens chosen belong to siliceous agglutinated, primitive species described and discussed by Krasheninnikov (1974). In addition, calcareous agglutinated species of Tritaxia and Dorothia are rather common.

The calcareous foraminiferal composition is quite diverse (Table 3), and is dominated by the genera Aragonia, Osangularia, and Globorotalites. Most specimens are well preserved, although etched surfaces and abundant dissolved fragments can be found. Sample 7-2, 107-108 $\mathrm{cm}$ contains few specimens of either agglutinated or calcareous foraminifers, and the calcareous specimens are severely etched and dissolved. Sample 7-2, 139-141 cm contains a rather well preserved and diverse calcareous assemblage dominated by species of Aragonia, Praebulimina, Osangularia, Gavelinella, and Alabamina. Gyroidinoides, Praebulimina, and Bolivina are fairly common, too. However, the residue contains abundant broken pieces of agglutinated foraminifers (e.g., genera Rhabdammina, Tritaxia, and Dorothia). Sample 7-3, 7-8 


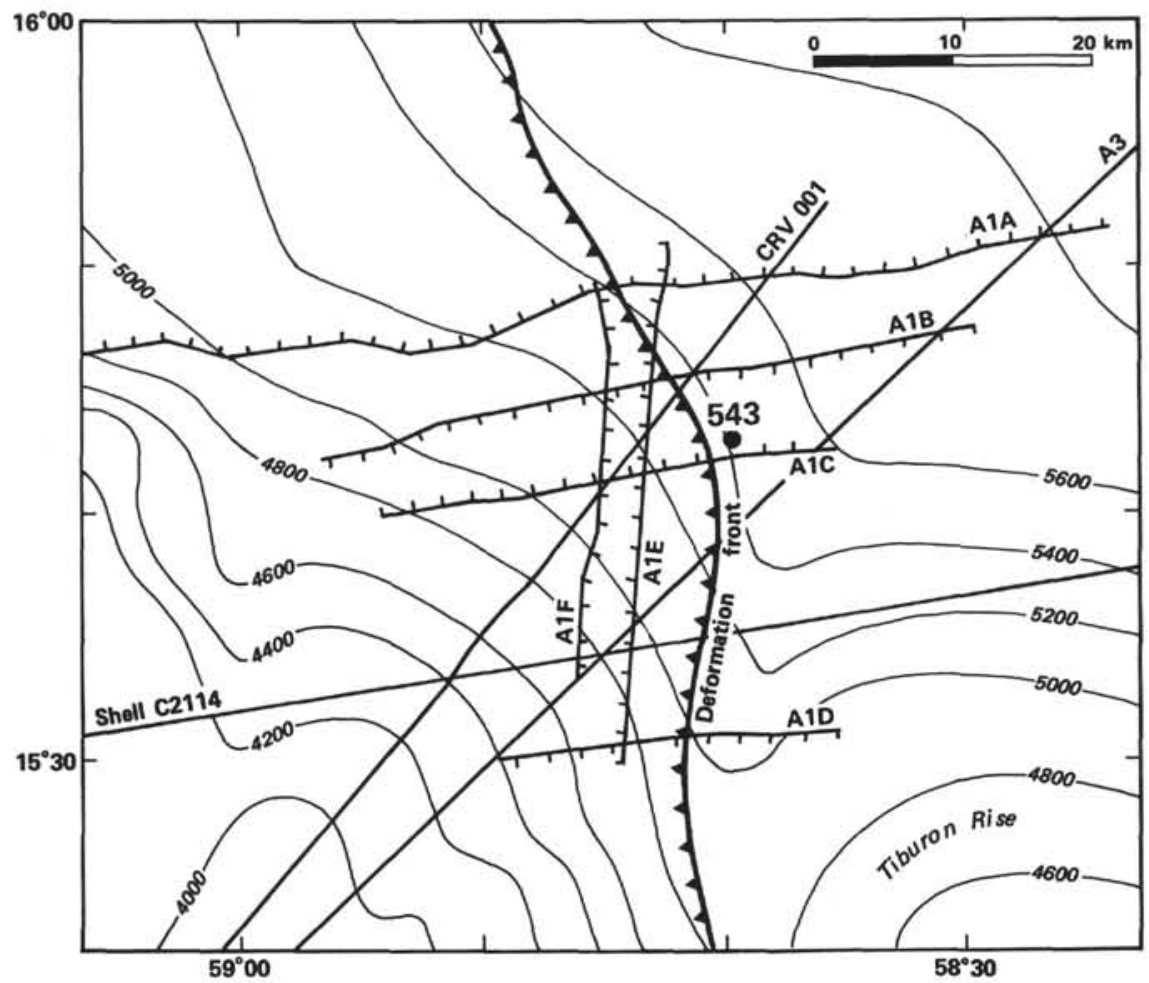

Figure 2. Detailed location map for Site 543. Depth contours in meters. Note the position of Site 543 on the Atlantic Plate. (From Moore et al., 1982.)

Table 1. Sequence of assemblages in Hole 543A, Sections 5-10.

\begin{tabular}{|c|c|c|}
\hline $\begin{array}{l}\text { Span or level } \\
\text { in core } \\
\text { (sample interval } \\
\text { in } \mathrm{cm} \text { ) }\end{array}$ & Assemblage & Assemblage type \\
\hline $\begin{array}{l}5-2,113-115 \\
\text { through } \\
6, C C\end{array}$ & 1 & $\begin{array}{l}\text { Siliceous agglutinated species; mainly } \\
\text { compressed tests. }\end{array}$ \\
\hline $\begin{array}{l}6, C C \\
\text { through } \\
7-1,146-148\end{array}$ & 2 & $\begin{array}{l}\text { Siliceous agglutinated species only; al } \\
\text { specimens well preserved }\end{array}$ \\
\hline $\begin{array}{l}7-2,73-75 \\
\text { through } \\
7-3,84-85\end{array}$ & $3+2$ & $\begin{array}{l}\text { Siliceous agglutinated species com- } \\
\text { bined with calcareous agglutinated } \\
\text { and calcareous species. }\end{array}$ \\
\hline $\begin{array}{l}7-4,4-6 \\
\text { through } \\
8, \mathrm{CC}\end{array}$ & 2 & Agglutinated species only. \\
\hline $9-1,44-46$ & $3 a+2$ & $\begin{array}{l}\text { Strongly reduced calcareous assem- } \\
\text { blage. }\end{array}$ \\
\hline $9, \mathrm{CC}(16-18)$ & $2 \mathrm{a}$ & Strongly reduced assemblage. \\
\hline $9, \mathrm{CC}$ & $3+2 a$ & $\begin{array}{l}\text { Agglutinated and calcareous species, } \\
\text { rather well preserved. }\end{array}$ \\
\hline $\begin{array}{l}10-1,1-3 \\
\text { through } \\
10-1,25-27\end{array}$ & 4 & $\begin{array}{l}\text { Agglutinated and calcareous species, } \\
\text { rather badly preserved. }\end{array}$ \\
\hline
\end{tabular}

$\mathrm{cm}$ contains a rather poor assemblage of both calcareous and agglutinated foraminifers. Despite the chalky surrounding sediment, the specimens are well preserved, and juveniles are present. Nevertheless, the dominating genera are still Osangularia, Globorotalites, Bolivina, and the praebuliminids. Sample 7-3, 73-75 $\mathrm{cm}$ represents the most diverse assemblage, consisting of 22 agglutinated and 35 calcareous species (assemblages 2 and 3 ). Compared with the agglutinated assemblage in Sample 7-1, $73-75 \mathrm{~cm}$, the agglutinated assemblage here is reduced not only in number of species, but also in specimens. Rhabdammina, Hyperammina, Tolypammina, and Hormosina are rather abundant among the agglutinated species; Aragonia, Praebulimina, Osangularia, and Globorotalites are the most frequent genera among the calcareous benthic foraminifers (assemblages 2 and 3 ).

Sample 7-3, 84-85 cm shows a rapid decrease in specimens, both calcareous and agglutinated forms, comparable in sparseness to Sample 7-2, 107-108 cm. Beginning at the top of Sample 7-4, 4-6 cm, a more or less carbonate-free sequence follows down the section, including Cores 8 and 9, except Sample 9-1, 44-46 cm and the bottom of Section 9,CC (assemblage 2). Sample 7-4, 4-6 cm and Section 7,CC are marked by a drastic change that results in increasing numbers of specimens and species of agglutinated foraminifers. Calcareous forms are absent, as are calcareous agglutinated species. However, a few corroded calcareous fragments of foraminifers and calcareous nannofossils indicate a rapidly increasing dissolution. The agglutinated fauna is characterized by 26 species of Rhabdammina, Hyperammina, Glomospira, Tolypammina, Hormosina, Haplophragmoides, Paratrochamminoides, and Pseudobolivina. This assemblage (assemblage 2) can be compared (Table 4) with faunas described by Krasheninnikov [Sites 196, 198 (Hole 198A), 367, and 368: Pacific and Indian oceans; Krasheninnikov $(1973,1974)]$. 


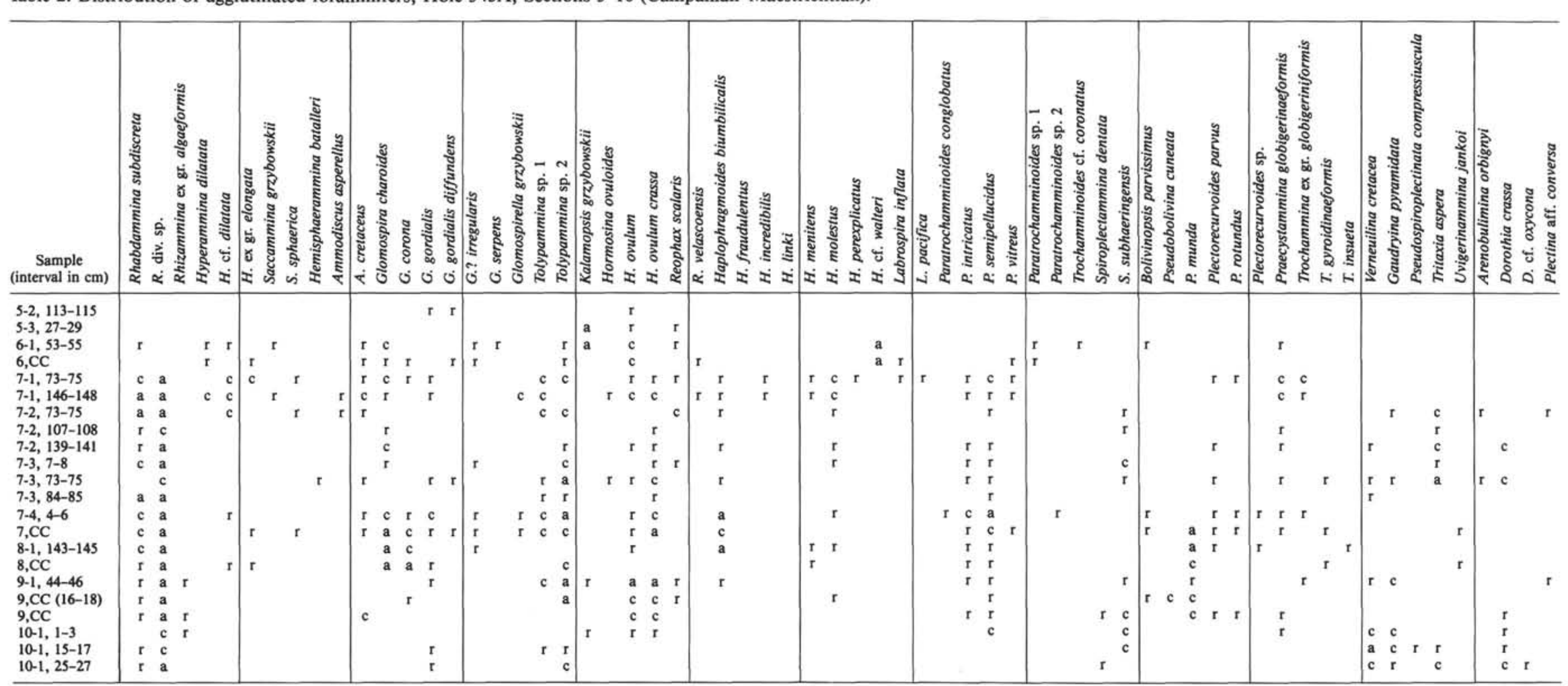

Note: $\mathrm{a}=$ abundant $(>10$ specimens), $\mathrm{c}=$ common $(5-10$ specimens), $\mathrm{r}=$ rare $(<5$ specimens $)$ 
Table 3. Distribution of calcareous foraminifers, Hole 543A, Sections 7-10 (Campanian-Maestrichtian).

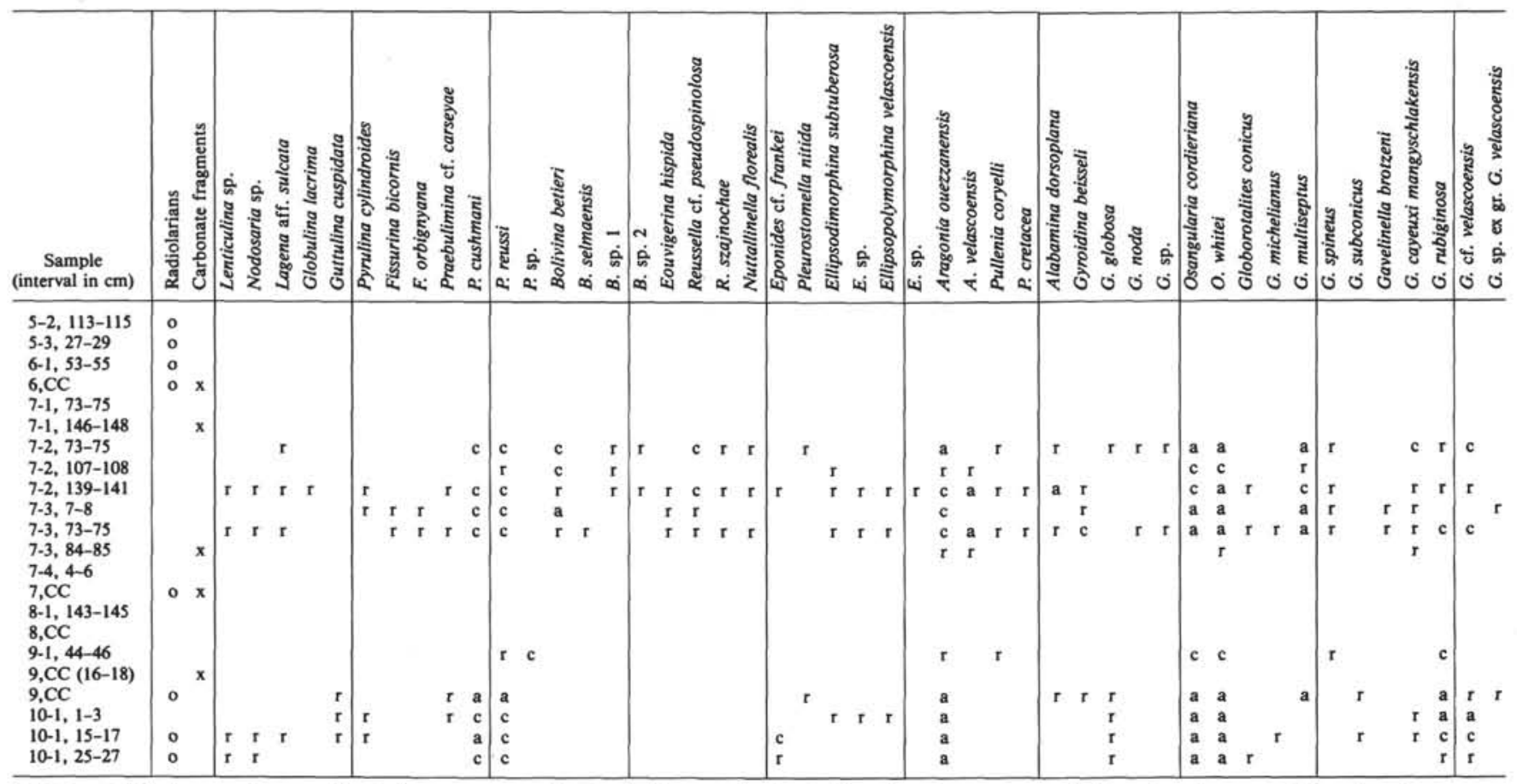

Note: $\mathrm{o}=$ radiolarians present; $\mathrm{x}=$ carbonate fragments present. For foraminifers, $\mathrm{a}=$ abundant $(>10$ specimens $), \mathrm{c}=$ common $(5-10$ specimens), $\mathrm{r}=$ rare $(<5$ specimens).

\section{Cores 8 and 9}

The next two samples taken down-section from the bottom of Core 7 (Sample 8-1, 143-145 cm and Section $8, C C)$ are characterized by an extremely well preserved agglutinated assemblage of low diversity (assemblages 2 and $2 \mathrm{a}$ ). The dominant species belong to the genera Glomospira, Haplophragmoides, and Pseudobolivina. This confirms the overall decrease of agglutinated species compared with the above-mentioned samples from Core 7.

Sample 9-1, 44-46 cm again contains calcareous species, as well as agglutinated foraminifers. Excluding from the latter group the siliceous agglutinating foraminifers, this part of the assemblage is rather diverse (19 species), and can be compared to samples from Sections 7-1, 7-4, and 7,CC. The calcareous foraminifers are moderately well preserved but less abundant and less diverse (eight species). Corroded and fragmented specimens are frequent (assemblage 3a).

Sample 9,CC $(16-18 \mathrm{~cm})$ again can be compared to Section $8, C C$, but is still less diverse, containing only 11 agglutinating forms. The dominance of genera Rhabdammina and Tolypammina is peculiar. Other common species belong to genera Hormosina and Pseudobolivina. Additionally, few calcareous fragments are present in this limited assemblage (assemblage 2a).

Below this, downward from Section 9,CC, samples contain more $\mathrm{CaCO}_{3}$, as indicated by the calcareous foraminifers and nannofossils. Section 9,CC is still, in number of specimens, dominated by agglutinated species, but the diversity can be compared to that in Sample $9, \mathrm{CC}(16-18 \mathrm{~cm})$. The calcareous assemblage is characterized by species of Osangularia, Aragonia, Ga- velinella, and Praebulimina; Reusella and Bolivina, common in Core 7, are absent here, and so are planktonic foraminifers (assemblage 3 ).

\section{Core 10 (Assemblage 4)}

The sedimentary interval of $37 \mathrm{~cm}$ recovered above basalt in Section 10-1 contains a mixed calcareous and agglutinated foraminiferal assemblage. The ratio of agglutinated to calcareous species is approximately $1: 2$. This is evidenced by the $\mathrm{CaCO}_{3}$ content of more than $50 \%$. Still, the $\mathrm{CaCO}_{3}$ content increases down the section in sediments interlayered with basalt pillows.

Sample 10-1, 1-3 cm contains a rather well preserved foraminiferal assemblage in which the calcareous agglutinated foraminifers become more abundant; siliceous agglutinated species are much less diverse and abundant, no longer comparable to the assemblages of Core 7 through 9. Corroded and fragmented calcareous species are common. Among the calcareous foraminifers, species of $\mathrm{Ara}$ gonia, Osangularia, Gavelinella, and the praebuliminids are most frequently observable. The bolivinids are absent. Samples 10-1, 15-17 cm and 10-1, 25-27 cm contain essentially the same basic calcareous foraminiferal assemblage, but preservation is different (assemblage 4a). Thus, Table 3 does not reflect the genuine frequency and composition of species in Sample 10-1, 25-27 cm. Most specimens are heavily encrusted by secondary calcite and/or etched. Still, the dominating genera are Aragonia, Osangularia, Gavelinella, and members of the buliminids. Among the rare species, both samples contain few nodosariids, possibly indicating a shallower depositional environment.

The oldest sediments recovered at Site 543 are lower Campanian, on the basis of nannofossils present (Bergen, 
Table 4. Comparison of the distribution of Upper Cretaceous agglutinated foraminifers, Legs 20, 27, 78A, and 41 .

\begin{tabular}{|c|c|c|c|c|}
\hline & $\begin{array}{c}\text { Krasheninnikov, } \\
\text { Leg } 20 \\
\text { (North Pacific) }\end{array}$ & $\begin{array}{c}\text { Krasheninnikov, } \\
\text { Leg } 27 \\
\text { (Indian Ocean) }\end{array}$ & $\begin{array}{l}\text { Hemleben and } \\
\text { Troester, } \\
\text { Leg 78A } \\
\text { (Western } \\
\text { North Atlantic) }\end{array}$ & $\begin{array}{c}\text { Krasheninnikov } \\
\text { and Pflaumann, } \\
\text { Leg 41 } \\
\text { (Eastern } \\
\text { North Atlantic) }\end{array}$ \\
\hline $\begin{array}{l}\text { Rhabdammina subdiscreta Grzy- } \\
\text { bowski }\end{array}$ & & & $\mathbf{x}$ & \\
\hline $\begin{array}{l}\text { R. div. sp. } \\
\text { Rhizammina algaeformis (Brady) }\end{array}$ & & & $\mathrm{x}$ & $x$ \\
\hline R. ex gr. algaeformis (Brady) & & & $\mathrm{x}$ & $x$ \\
\hline $\begin{array}{l}\text { Psammosiphonella alexanderi } \\
\text { (Cushman) }\end{array}$ & & & & $\mathrm{x}$ \\
\hline $\begin{array}{l}\text { P. anglesianensis (Crespin) } \\
\text { P. cylindrica (Glaessner) }\end{array}$ & & & & $\begin{array}{l}\mathrm{x} \\
\mathrm{x}\end{array}$ \\
\hline Hyperammina dilatata Grzybowski & & & $\mathrm{x}$ & \\
\hline $\begin{array}{l}\text { H. cf. dilatata Grzybowski } \\
H \text {. ex gr. elongata Brady }\end{array}$ & $\mathrm{x}$ & & & \\
\hline $\begin{array}{l}\text { H. ex gr. elongata Brady } \\
\text { H. friabilis Brady }\end{array}$ & $\mathrm{x}$ & $\mathrm{x}$ & $\mathrm{x}$ & $x$ \\
\hline H. gaultina ten dam & & & & $\hat{x}$ \\
\hline H. subnodosa Brady & & & & $\mathrm{x}$ \\
\hline Dendrophyra excelsa Grzybowski & & & & $\mathrm{x}$ \\
\hline Saccammina complanata (Franke) & & & & $\mathrm{x}$ \\
\hline $\begin{array}{l}\text { S. grzybowskii (Schubert) } \\
\text { S. placenta (Grzybowski) }\end{array}$ & & & $\mathrm{x}$ & \\
\hline $\begin{array}{l}\text { S. placenta (Grzybowski) } \\
\text { S. sphaerica M. Sars }\end{array}$ & & & & $\mathrm{x}$ \\
\hline $\begin{array}{l}\text { Pilulina antiqua Krasheninnikov } \\
\text { Hemisphaerammina batalleri Loeblich }\end{array}$ & & $\mathrm{x}$ & $\mathrm{x}$ & \\
\hline & & & $\mathrm{A}$ & \\
\hline $\begin{array}{l}\text { Ammodiscus aspenellus Krasheninni- } \\
\text { kov }\end{array}$ & $\mathrm{x}$ & & $\mathrm{x}$ & \\
\hline A. cretaceus (Reuss) & & $\mathbf{x}$ & $\mathrm{x}$ & $\mathbf{x}$ \\
\hline A. cretaceous rugasus Schijfsma & & $\mathrm{x}$ & & \\
\hline $\begin{array}{l}\text { A. glabratus Cushman and Jarvis } \\
\text { A. pennyi Cushman and Jarvis }\end{array}$ & & & & $\begin{array}{l}x \\
x\end{array}$ \\
\hline $\begin{array}{l}\text { Glomospira charoides (Jones and } \\
\text { Parker) }\end{array}$ & $x$ & $\mathrm{x}$ & $\mathrm{x}$ & $\mathrm{x}$ \\
\hline $\begin{array}{l}\text { G. corona Cushman and Jarvis } \\
\text { G. gordialis (Jones and Parker) }\end{array}$ & & $\mathrm{x}$ & $\mathrm{x}$ & $\mathrm{x}$ \\
\hline $\begin{array}{l}\text { Gendialis diffundens Cushman and } \\
\text { Renz }\end{array}$ & & & $\mathrm{x}$ & \\
\hline $\begin{array}{l}\text { G.? irregularis (Grzybowski) } \\
\text { G. serpens (Grzybowski) }\end{array}$ & & & $\mathrm{x}$ & \\
\hline $\begin{array}{l}\text { G. serpens (Grzybowski) } \\
\text { Glomospirella gaultina (Berthelin) }\end{array}$ & $\mathrm{x}$ & $\mathrm{x}$ & $\mathrm{x}$ & $x$ \\
\hline G. grzybowskii (Jurkiewicz) & & & $x$ & \\
\hline Tolypammina sp. 1 & $\mathrm{x}$ & $\underset{\mathrm{x}}{\mathbf{x}}$ & $\underset{x}{x}$ & \\
\hline $\begin{array}{l}\text { T. sp. } 2 \\
\text { Kalamopsis grzybowskii (Dylazanka) }\end{array}$ & & $\mathrm{x}$ & $\begin{array}{l}x \\
x\end{array}$ & $\mathrm{x}$ \\
\hline Hormosina ovuloides (Grzybowski) & & & $\mathrm{x}$ & \\
\hline H. ovulum (Grzybowski) & $\mathrm{x}$ & $\mathbf{x}$ & $\mathrm{x}$ & $\mathrm{x}$ \\
\hline H. ovuhum crassa Geroch & $\mathrm{x}$ & & $\mathrm{x}$ & \\
\hline $\begin{array}{l}\text { Reophax pilulifer Brady } \\
R \text {. scalaris Grzybowski }\end{array}$ & & & $x$ & $\mathrm{x}$ \\
\hline R. velascoensis (Cushman) & & & $\hat{x}$ & \\
\hline $\begin{array}{l}\text { Rzehakina epigona epigona (Rzehak) } \\
\text { R. fissastomata (Grzybowski) }\end{array}$ & & & & $\begin{array}{l}x \\
x\end{array}$ \\
\hline$R$, inclusa (Grzybowski) & & & & $\hat{x}$ \\
\hline Silicosigmoilina perplexa Israelsky & & & & $\mathrm{x}$ \\
\hline $\begin{array}{l}\text { Haplophragmoides biumbilicalis } \\
\text { Krasheninnikov }\end{array}$ & $\mathrm{x}$ & & $\mathrm{x}$ & \\
\hline H. breviculus Krasheninnikov & $\mathrm{x}$ & & & \\
\hline H. bulloides (Beissel) & & $\mathrm{x}$ & & \\
\hline H. constrictus Krasheninnikov & $\mathrm{x}$ & $\underset{x}{x}$ & & \\
\hline $\begin{array}{l}\text { H. decussatus Krasheninnikov } \\
\text { H. fraudulentus Krasheninnikov }\end{array}$ & $\underset{x}{x}$ & $\begin{array}{l}\mathrm{x} \\
\mathrm{x}\end{array}$ & $x$ & \\
\hline $\begin{array}{l}\text { H. fraudulentus Krasheninnikov } \\
H \text {. incredibilis Krasheninnikov }\end{array}$ & $\mathrm{x}$ & $\begin{array}{l}x \\
x\end{array}$ & $\hat{x}$ & \\
\hline $\begin{array}{l}\text { H. incredibilis Krasheninnikov } \\
\text { H. linki Nauss }\end{array}$ & & $\mathrm{x}$ & $\widehat{x}$ & \\
\hline H. menitens Krasheninnikov & & $\mathrm{x}$ & $\mathrm{x}$ & \\
\hline H. molestus Krasheninnikov & $\mathrm{x}$ & & $\mathrm{x}$ & \\
\hline H. multicamerus Krasheninnikov & $\mathrm{x}$ & $\mathrm{x}$ & & \\
\hline H. multiformis Krasheninnikov & & $\underset{x}{x}$ & $\underset{\mathrm{x}}{\mathrm{x}}$ & \\
\hline H. perexplicatus Krasheninnikov & $\mathrm{x}$ & $\mathrm{x}$ & $\mathrm{x}$ & \\
\hline $\begin{array}{l}\text { H. pervagatus Krasheninnikov } \\
H \text {. pseudokirki Krasheninnikov }\end{array}$ & $\mathrm{x}$ & $\mathrm{x}$ & & \\
\hline H. cf. watteri (Grzybowski) & & & $\mathrm{x}$ & \\
\hline $\begin{array}{l}\text { H. sp. } \\
\text { Labrospina inflata Krasheninnikov }\end{array}$ & & & & $\mathbf{x}$ \\
\hline $\begin{array}{l}\text { Labraspina inflata Krasheninnikov } \\
\text { L. pacifca Krasheninnikov }\end{array}$ & $\mathrm{x}$ & $\begin{array}{l}x \\
x\end{array}$ & $\begin{array}{l}x \\
x\end{array}$ & \\
\hline $\begin{array}{l}\text { L. pacifca Krasheninnikov } \\
\text { Paratrochamminoides conglobatus } \\
\text { (Brady) }\end{array}$ & & & $\begin{array}{l}\mathbf{X} \\
\mathbf{x}\end{array}$ & \\
\hline P. corpulentus Krasheninnikov & $\mathrm{x}$ & & & \\
\hline$P$. intricatus Krasheninnikov & $\mathrm{x}$ & $\mathrm{x}$ & $\mathbf{x}$ & \\
\hline P. semipellucidus Krasheninnikov & $\mathrm{x}$ & & $\mathbf{x}$ & \\
\hline $\begin{array}{l}P . \text { vitreus Krasheninnikov } \\
P . \text { sp. }\end{array}$ & $\mathrm{x}$ & $\mathrm{x}$ & $\begin{array}{l}x \\
x\end{array}$ & \\
\hline $\begin{array}{l}\text { P. sp. } 1 \\
P . \text { sp. } 2\end{array}$ & & & $\begin{array}{l}x \\
x\end{array}$ & \\
\hline$P$. div. sp. & & & & $\mathrm{x}$ \\
\hline $\begin{array}{l}\text { Recurvoides ex gr. deflexiformis } \\
\text { (Noth) }\end{array}$ & & $\mathrm{x}$ & & \\
\hline R. gerochi Pflaumann & & & & $\mathrm{x}$ \\
\hline R. pentacameratus Krasheninnikov & & $\mathbf{x}$ & & \\
\hline R. pseudosymmetricus Krasheninnikov & & $\mathbf{x}$ & & \\
\hline
\end{tabular}


Table 4. (Continued.)

\begin{tabular}{|c|c|c|c|c|}
\hline & $\begin{array}{c}\text { Krasheninnikov, } \\
\text { Leg } 20 \\
\text { (North Pacific) }\end{array}$ & $\begin{array}{c}\text { Krasheninnikov, } \\
\text { Leg } 27 \\
\text { (Indian Ocean) }\end{array}$ & $\begin{array}{c}\text { Hemleben and } \\
\text { Troester, } \\
\text { Leg 78A } \\
\text { (Western } \\
\text { North Atlantic) }\end{array}$ & $\begin{array}{l}\text { Krasheninnikov } \\
\text { and Pflaumann, } \\
\text { Leg } 41 \\
\text { (Eastern } \\
\text { North Atlantic) }\end{array}$ \\
\hline $\begin{array}{l}\text { Thalmannammina cf. subturbinata } \\
\text { (Grzybowski) }\end{array}$ & & & & $\mathbf{x}$ \\
\hline Thochamminoides coronatus (Brady) & & & & $\mathbf{x}$ \\
\hline$T$. cf. coronatus (Brady) & & & $\mathbf{x}$ & \\
\hline T. proteus (Karrer) & & & & $\mathbf{x}$ \\
\hline $\begin{array}{l}\text { Haplophragmium lueckei (Cushman } \\
\text { and Hedberg) }\end{array}$ & & $\mathbf{x}$ & & \\
\hline Spiroplectammina dentata (Alth) & & & $\mathbf{x}$ & \\
\hline S. subhaeringensis (Grzybowski) & & & $\mathbf{x}$ & \\
\hline Bolivinopsis abyssalis Krasheninnikov & & $\mathbf{x}$ & $\mathbf{x}$ & \\
\hline B. parvissimus Krasheninnikov & $\mathbf{x}$ & $\mathrm{x}$ & $\mathbf{x}$ & \\
\hline $\begin{array}{l}\text { Pseudobolivina cuneata Krasheninni- } \\
\text { kov }\end{array}$ & & $\mathrm{x}$ & $x$ & \\
\hline P. lagenaria Krasheninnikov & & $\mathbf{x}$ & & \\
\hline P. munda Krasheninnikov & $\mathrm{x}$ & $\mathbf{x}$ & $\mathbf{x}$ & \\
\hline P. normalis Krasheninnikov & & $\mathrm{x}$ & & \\
\hline $\begin{array}{l}\text { Plectorecurvoides parvus Krasheninni- } \\
\text { kov }\end{array}$ & $\mathbf{x}$ & $\mathrm{x}$ & $\mathbf{x}$ & \\
\hline P. rotundus Krasheninnikov & & & $\mathbf{x}$ & $\mathbf{x}$ \\
\hline$P$ sp. & & & $\mathbf{x}$ & \\
\hline $\begin{array}{l}\text { Praecystammina globigerinaeformis } \\
\text { Krasheninnikov }\end{array}$ & $\mathbf{x}$ & $\mathbf{x}$ & $\mathbf{x}$ & \\
\hline $\begin{array}{l}\text { Trochammina globigeriniformis alti- } \\
\text { formis Cushman and Renz }\end{array}$ & & $\mathrm{x}$ & & \\
\hline $\begin{array}{l}\text { T. ex gr. globigeriniformis (Parker and } \\
\text { Jones) }\end{array}$ & & & $\mathbf{x}$ & \\
\hline T. gyroidinaeformis Krasheninnikov & & $\mathbf{x}$ & $\mathbf{x}$ & \\
\hline T. insueta Krasheninnikov & & $\mathrm{x}$ & $\mathrm{x}$ & \\
\hline T. lobulata Krasheninnikov & & $\ddot{x}$ & & \\
\hline T. pseudovesicularis Krasheninnikov & & $\mathbf{x}$ & & \\
\hline Verneuilina cretacea Karrer & & $\mathrm{x}$ & $\mathbf{x}$ & \\
\hline Gaudryina pyramidata Cushman & & & $\mathrm{x}$ & \\
\hline $\begin{array}{l}\text { Pseudospiroplectinata compressiuscula } \\
\text { (Chapman) }\end{array}$ & & & $\mathbf{x}$ & \\
\hline \multicolumn{5}{|l|}{ Tritaxia aspera (Cushman) } \\
\hline Uvigerinammina jankoi Majzon & & $\mathbf{x}$ & $\mathbf{x}$ & $\mathbf{x}$ \\
\hline Arenobulimina orbignyi (Reuss) & & & $\mathbf{x}$ & \\
\hline Dorothia crassa (Marsson) & & & $\mathrm{x}$ & \\
\hline D. oxycona (Reuss) & & & $\mathbf{x}$ & \\
\hline D. cf. oxycona (Reuss) & & & $\mathbf{x}$ & \\
\hline Plectina conversa (Cushman) & & & & $\mathbf{x}$ \\
\hline P. aff. conversa (Grzybowski) & & $\mathbf{x}$ & $\mathbf{X}$ & \\
\hline
\end{tabular}

this volume). Reddish limestone interlayered with basaltic pillow lavas contains a few radiolarians [Sample 543A-12-3 (Piece 4B, 78-81 cm)].

Summarizing the data from bottom to top of Hole 543A, we get the following impression (Table 1):

1) The top of Core 10 is characterized by the first occurrence of a chalky, white-reddish sediment containing indeterminable fossil fragments, possibly lower Campanian.

2) From Core 10 upward, there is a continuous Campanian to Maestrichtian sedimentary section.

3) Samples from this interval contain a benthic foraminiferal assemblage of a composition which varies with respect to agglutinating and/or calcareous species (Table 1). Some of these samples seem to be relatively heterogeneous in relation to their overall composition.

4) From Sample 7-1, 146-148 cm upward, the samples contain only agglutinating foraminifers. The assemblages become less diverse, and preservation becomes poorer upward in the hole.

5) Core 4 lacks benthic microfossil communities; only radiolarians are present.

\section{BIOSTRATIGRAPHY}

Abyssal deep-water successions of benthic foraminifers are not yet well known, because of missing land outcrops, poor preservation, sparseness of drilling sites at ridge-crest positions, or even taxonomic differences. Conflicting biostratigraphic results are therefore common when nannofossils and benthic foraminifers are used. Core 543A-5 has been classified from its radiolarians (Renz, this volume) as upper lower Eocene. Core 543A-6 is barren of calcareous and siliceous fossils, but contains some specimens of agglutinating foraminifers, such as $\mathrm{Hy}$ perammina dilatata, Saccammina grzybowskii, Reophax velascoensis, and Haplophragmoides cf. walteri. These four species are restricted to Core 6, and do not occur elsewhere. Core 7 is supposed to be Maestrichtian to Campanian, on the basis of its nannofossils (Bergen, this volume). Samples from Core 7 contain a calcareous assemblage suggesting the same chronostratigraphic classification. Following Sliter (1977b), the proposed assignment would be based on the presence of Spiroplectammina dentata, Gaudryina pyramidata, Aragonia ouezzanensis, and Gavelinella cayeuxi mangyschlakensis. All of these definitely occur in Core 10 , which, on the evidence of its nannofossils, is lower Campanian. However, Bolivina betieri, Eouvigerina hispida, and Pullenia coryelli occur in Core 7 only, and these are known as restricted to the Maestrichtian to upper Campanian. Therefore a Campanian assignment for Core 10 and an upper 
Campanian to Maestrichtian assignment for Core 7 do seem reasonable.

\section{ENVIRONMENTAL INTERPRETATION}

With regard to foraminiferal composition, the sedimentary section we have described may be explained by the following model: The first occurrence of calcareous benthic foraminifers in Core 543A-10 may indicate a depositional environment above the CCD but well below the foraminiferal lysocline, since planktonic foraminifers are for the most part absent. Upward in the hole, beginning at Sample 9,CC (44-46 cm), the increasing diversity of agglutinated foraminifers indicates that the depositional environment dropped below the CCD. The maximum diversity of agglutinated species occurs in Sections 7-4 and 7,CC (assemblage 2). According to comparable assemblages of siliceous agglutinated foraminifers described by Krasheninnikov $(1973,1974)$, the seafloor must have reached a water depth of $5000-6000 \mathrm{~m}$. This would imply that all calcareous forms in Cores 9 through 7 (assemblage 3) were transported downslope-by, for example, bottom currents. This would explain especially the occurrence of calcareous agglutinated species and some forms usually living higher upslope-for example, nodosariids and buliminids, including the bolivinids. For a more detailed model of the depositional environment, we must, however, realize the following facts:

1) Planktonic foraminifers are absent in all samples investigated, except for a few questionable specimens found in samples from Core 10. This may indicate a depositional environment at the CCD, well below the foraminiferal lysocline.

2) Neoflabellina, Stensioina, and Bolivinoides species and other shallow-water forms are absent, evidencing a lower bathyal or abyssal depositional environment; praebuliminids and reussellids are present.

3) No steinkerns or molds of either benthic or planktonic foraminifers are present. Except in Core 10, most calcareous specimens are empty. Corroded and fragmented specimens are common in all "calcareous samples." This suggests sediment deposition close to the $\mathrm{CCD}$, or transportation from this level downslope. Transportation from higher upslope would imply the occurrence of planktonic foraminifers.

4) Calcareous agglutinated foraminifers occur together with calcareous foraminifers only (assemblage 3 ).

5) In "calcareous samples" the siliceous agglutinated forms are less diverse and less frequent. This may be a result of faunal dilution, or it could be explained by changing environment (e.g., food supply, water chemistry, etc.).

6) The most frequent calcareous species (e.g., species of Osangularia, Gavelinella, Globorotalites, Aragonia, and Praebulimina) occur in most calcareous samples. Thus, the basic calcareous assemblage remains the same. On the other hand, all samples (except those from Section 9,CC downward) contain a basic siliceous agglutinated assemblage consisting of species of Rhabdammina, Hyperammina, Glomospira, Tolypammina, Hormosina, Paratrochamminoides, and Praecystammina.
7) Apparent abrupt changes in the faunal composition suggest transportation again. However, samples taken nearby the "calcareous samples" up or down section contain nannofossils and/or carbonate remains (Table 3). Thus, the apparent abrupt changes are in reality fairly smooth, and suggest a depositional environment gradually changing with respect to the CCD.

In addition, we have to consider the geographic and bathymetric position of the basement and of the overlying sedimentary sequence (Cores 10-12). Using the backtracking method or the data compiled by Berger and Winterer (1974) or Detrick et al. (1977), a water depth of 2500-2800 m seems reasonable for the crest of the Mid-Atlantic Ridge during the Campanian. Using these data, we reason that the water depth was approximately $4000 \mathrm{~m}$ after 10-15 Ma (late Maestrichtian) and $5500 \mathrm{~m}$ during deposition of the radiolarian oozes of the Eocene. Following Sliter (1977b) in assuming that the Late Cretaceous lysocline and carbonate compensation surface (CCS) ranged between 3000 and $4000 \mathrm{~m}$ in the South Atlantic, we may consider this range to be about right for Site 543, especially on the evidence of Core 7.

A certain heterogenity of the assemblage composition (assemblages 2 and 3) in Samples 7-2, 73-75 cm through 7-3, 84-85 $\mathrm{cm}$ may contradict this assumption. Species of Aragonia, Bolivina, Gavelinella, Globorotalites, Osangularia, and Praebulimina occur together and are widely dominant in our samples. Comparing this association with the associations at Sites 355 and 358 of Leg 39, we have to consider a water depth of 3000 to $4000 \mathrm{~m}$, according to Sliter (1977b). However, samples from these sites lack most of the praebuliminids, reusselids, and other species usually living higher upslope. In contrast with Cores 357-32 and 357-33 (Maestrichtian), the samples from Core 543A-7 lack planktonic foraminifers as well as the dominance of genera like Gyroidinoides, Nuttallinella, Pullenia, and Quadrimorphina, recorded by Sliter. These contradictory results can be explained by downslope transport having caused a mixed assemblage. This implies that the source must have been at the crest areas of the Mid-Atlantic Ridge during the Maestrichtian.

But again, the missing planktonic foraminifers, and the etched and fragmented benthic specimens, would place this source area close to the CCD. The lithology also argues against transport, which would imply sedimentary structures such as gravity flows with thin layers rich in calcareous foraminifers, or size-sorted layers. But reworking, other than bioturbation and artifical displacement by drilling disturbance, were not observed. This means we have to consider about the same situation as that prevailing during the Campanian: a Mid-Atlantic Ridge crest at a water depth of about $2700 \mathrm{~m}$.

Another interpretation would explain this heterogenity of the "calcareous samples" of Core 7 as resulting from overlap of two different depth ranges of abyssal foraminiferal assemblages, biased by the CCD.

Summarizing the data and our observations, we propose the following model: Using assemblage composition and preservation, the lithology, and the literature, 
we will now try to reconstruct the changing level of the CCD and/or subsidence of the seafloor. The Mid-Atlantic Ridge crest may have reached up to approximately $2700 \mathrm{~m}$, still below the calcite compensation surface (CCS). Nannofossils and a selected calcareous benthic fauna characterizes the sequence overlying the basement. The assumed planktonic assemblage remains only in a few fragments and specimens. The following samples are evidence for subsidence below the CCD: Sample 9-1, 44-46 cm represents only a short period of deposition above the CCD, in an environment positioned well below the CCS. Sediments from Sections 7-4 through $8, \mathrm{CC}$ were deposited below the CCD but close to it, as indicated by calcareous fragments (e.g., Section 7,CC). If we assume a Campanian/Maestrichtian boundary in Core 8 , we might conclude a $3500-\mathrm{m}$ water depth, according to the age-depth relationship (Berger and Winterer, 1974). The "calcareous samples" of Core 7 (Maestrichtian), considered as an abyssal benthic community, may have lived under about $4000 \mathrm{~m}$ of water. This implies a rising CCD during this period, which fits well with the worldwide regression at the end of the Cretaceous. From Section 7-2 upward, the evidence is that the CCD followed the subsiding sea floor. Sample 7-2, 73$75 \mathrm{~cm}$ contains an abyssal agglutinated and calcareous foraminiferal assemblage; Sample 7-1, 146-148 cm, containing only a few fragments of calcareous foraminifers in addition to an abyssal agglutinated assemblage, can already be positioned as deposited below the CCD. Finally, Sample $7-1,73-75 \mathrm{~cm}$ contains only a highly diverse siliceous agglutinated fauna, which becomes strongly reduced upward in the hole into Tertiary sediments deposited well below the CCD.

\section{CONCLUSIONS}

On the basis of the benthic assemblages, we conclude that there was a slowly oscillating CCD at the end of the Cretaceous. The alternative, downslope transportation, would imply a subsidence rate which seems too high, according to our knowledge. Thus, the fossil assemblage composition reflects the overlap of siliceous agglutinated and calcareous species. Further detailed work will be necessary to evaluate the true depth range for all species found.

\section{ANNOTATED SPECIES LIST ${ }^{3}$}

Alabamina dorsoplana (Brotzen)

(Plate 5, Figs. 17 and 18)

Eponides dorsoplana Brotzen, 1940, p. 31, figs. 8 and 2.

A. dorsoplana occurs in Cores 543A-9 and 543A-7 only, possibly indicating that Core 543A-10 is lower Campanian. (upper CampanianMaestrichtian.)

\section{Ammodiscus asperellus Krasheninnikov}

$$
\text { (Plate 1, Fig. 16) }
$$

A. asperellus Krasheninnikov, 1973, p. 211, pl. 3, fig. 6.

We found only one individual which could be assigned to this species. (Santonian-Maestrichtian.)

\footnotetext{
${ }^{3}$ For most well-known species see Ellis and Messina (1940) for further citations.
}

Ammodiscus cretaceus (Reuss)

(Plate 1, Fig. 17)

Operculina cretacea Reuss, 1845, p. 35, pl. 13, figs. 64 and 65 . A. cretaceus (Reuss), Krasheninnikov, 1974, p. 643, pl. 7, fig. 8.

A. cretaceus (Reuss), Sliter, 1977a, pl. 1, fig. 3.

This cosmopolitan species occurs only very scarcely in our material, mainly in Core 7. A comprehensive taxonomic discussion has been published by Krasheninnikov (1974). (Albian-Maestrichtian.)

\section{Aragonia ouezzanensis (Rey)}

(Plate 6, Fig. 11)

Bolivinoides ouezzanensis Rey, 1954, p. 210, pl. 12, fig. 2.

This species occurs most frequently in all samples containing carbonate and is well preserved; even specimens from Core 10 are very well preserved and abundant. (Santonian-Paleocene.)

\section{Aragonia velascoensis (Cushman)}

(Plate 6, Fig. 12)

Textularia velascoensis Cushman, 1925 , pl. 3 , figs. 1a-c.

This species occurs less frequently than $A$. ouezzanensis, but again it is very well preserved. The rims of the ornamentation vary greatly and demonstrate a close relationship to A. trinitatensis (Cushman and Jarvis). (Santonian-Paleocene.)

\section{Arenobulimina d'orbignyi (Reuss)}

(Plate 4, Fig. 21)

Bulimina d'orbignyi Reuss, 1845, p. 38, pl. 13, fig. 74.

Occurrence in "calcareous" samples only. (Turonian-Maestrichtian.)

\section{Bolivina betieri Drooger}

(Plate 5, Fig. 10 and 11)

B. betieri Drooger, 1952, p. 97 , pl. 15, figs. 29 and 30.

Specimens of this species closely resemble $B$. crenulata Cushman 1936 from the Paleocene Coal Bluff marl of the Gulf Coast region. They are rather common throughout the calcareous parts of the Maestrichtian-Paleocene section.

\section{Bolivina sp. 1}

(Plate 5, Figs. 12 and 13)

This species may belong to the Bolivinoides laevigatus group, but since only three specimens were found, we need more material for any further decision.

?Bolivina sp. 2

(Plate 5, Figs. 14 and 15)

This species occurs rather commonly in samples from Core 7 . The reticulate ornamentation resembles similar patterns found in Aragonia velascoensis and $A$. trinitatensis. (Maestrichtian.)

\section{Bolivinopsis parvissimus Krasheninnikov} (Plate 4, Fig. 1)

B. parvissimus Krasheninnikov, 1973, p. 210, pl. 2, figs. 8 and 9. Very small tests with diameters up to $0.07 \mathrm{~mm}$. (Santonian-Maestrichtian.)

\section{Dorothia crassa (Marsson)}

(Plate 4, Fig. 22)

Gaudryina crassa Marsson, 1878, pl. 158, pl. 3, figs. 27a-27c.

This species exhibits a rounded spiral side. This feature separates D. crassa from D. oxycona. A detailed discussion has been published by Huss (1966) and by Liszka and Liszkowa (1981). (Upper Cretaceous-Paleocene.)

\section{Dorothia cf. oxycona (Reuss)}

(Plate 4, Fig. 23)

Gaudryina oxycona Reuss, 1860, p. 229, pl. 12, figs. 3a-3c. Only a few specimens of juvenile stages were found. 


\section{Ellipsodimorphina subtuberosa Liebus}

(Plate 6, Fig. 7)

E. subtuberosa Liebus, 1928 , p. 89 , pl. 33 , figs. $34 \mathrm{a}$ and $34 \mathrm{~b}$.

This very rare species is very well preserved, as are all members of the pleurostomellids. (Coniacian-Maestrichtian.)

\section{Ellipsodimorphina sp.}

(Plate 6, Fig. 8)

Only one specimen has been observed, in Sample 7-2, 139-141 cm.

\section{Ellipsopolymorphina velascoensis (Cushman)}

(Plate 6, Fig. 9)

Ellipsoglandulina velascoensis Cushman, 1926, p. 590, pl. 16, figs. $7 \mathrm{a}-7 \mathrm{~b}$.

The specimens from Leg 78 are very comparable to those figured by Sliter (1977b). They are usually very well preserved but rather scarce. (Upper Campanian-Maestrichtian.)

\section{Ellipsopolymorphina sp.}

(Plate 5, Fig. 10)

Only one specimen was found, in Sample 7-3, 139-141 cm.

\section{Eouvigerina hispida Cushman \\ (Plate 5, Figs. 16 and 17)}

E. hispida Cushman, 1931, p. 45, pl. 7, figs. 12 and 13.

Only a few specimens were found, in Core 7. (Maestrichtian.)

\section{Eponides cf. frankei Brotzen}

(Plate 6, Figs. 4 and 5)

E. frankei Brotzen, 1940.

This species occurs in most samples, but is always very rare.

\section{Fissurina bicornis Neagu (Plate 4, Fig. 4)}

F. orbignyana bicornis Neagu, 1968, p. 225, pl. 2, figs. 9 and 10. The two basal spines are mostly broken, but still visible. (Campanian-Maestrichtian.)

\section{Fissurina orbignyana Sequenza}

$$
\text { (Plate 5, Fig. 5) }
$$

F. orbignyana Sequenza, 1862, p. 66, pl. 2, figs. 24 and 26.

Lagena orbignyana (Sequenza), Cushman and Jarvis, 1932, p. 40, pl. 12 , figs. $7 \mathrm{a}$ and $7 \mathrm{~b}$.

This species occurs in Core 7 samples only; it is generally moderately well preserved. (Santonian-Maestrichtian.)

\section{Gaudryina pyramidata Cushman}

(Plate 4, Figs. 16 and 17)

G. laevigata Franke var. pyramidata Cushman, 1926, p. 587, pl. 16, figs. 8a-b.

G. pyramidata Cushman, Sliter, 1977a, p. 675, pl. 2, fig. 9.

The juvenile stages found in our samples can be easily misinterpreted as Verneuilina sp. The type of agglutination and the typically high sutures are the distinguishing features, as compared with $V$. cretacea Karrer. (Turonian-Paleocene.)

\section{Gavelinella brotzeni Said and Kenawy}

(Plate 8, Figs. 3-5)

G. brotzeni Said and Kenawy, 1956, p. 147, pl. 4, fig. 47 .

This species occurs in Sample 7-3, 73-75 cm, the richest sample. The lobate spiral suture seems to be very typical of this species. (Coniacian-Maestrichtian.)

\section{Gavelinella cayeuxi mangyschlakensis (Vasilenko)} (Plate 8, Figs. 6-9)

Anomalina cayeuxi mangyschlakensis Vasilenko, 1954, p. 96, pl. 11, fig. 1 and pl. 12, figs. $1 \mathrm{a}$ and $1 \mathrm{~b}$.

This species occurs rather scarcely throughout the section. (Campanian-Paleocene.)

\section{Gavelinella rubiginosa (Cushman)}

(Plate 8, Figs. 10 and 11)

Anomalina rubiginosa Cushman, 1926, p. 607, pl. 2, figs. 6a-6c.

This species occurs more often in Core 10 than in Core 7. Most specimens are therefore rather badly preserved. (Maestrichtian-Paleogene.)

\section{Gavelinella cf. velascoensis (Cushman) \\ (Plate 8, Figs. 12, 13, 17)}

Anomalina velascoensis Cushman, 1925, p. 21, pl. 3, figs. 3a-3c.

The specimens of our material are very thick-walled and more involute than those figured by Sliter $(1968$, p. 125, pl. 23, figs. 9a-9c). (Campanian-Paleocene.)

\section{Gavelinella sp. ex gr. G. velascoensis (Cushman)}

(Plate 8, Figs. 14-16)

This species belongs to the $G$. velascoenis group, but differs somewhat in shape and ornamentation.

\section{"Gavelinopsis" involutiformis Hofker}

(Plate 8, Figs. 18 and 19)

G. involutiformis Hofker, 1956, p. 74, fig. 63.

This species is common in all samples from Core 7, and in good agreement with Hofker's subsequent figuration (1957, p. 340, Abb. 391d).

\section{Globorotalites conicus (Carsey)}

(Plate 7, Figs. 16 and 17)

Truncatulina refulgens (Montfort), var. conica Carsey, 1926, p. 46, pl. 4 , fig. 15 .

All species of the genus Globorotalites are rather scarcely distributed, but all are well preserved. G. conicus occurs only in Core 7. (Coniacian-Maestrichtian.)

\section{Globorotalites multiseptus (Brotzen)}

Globorotalia multisepta Brotzen, 1936, pl. 161, pl. 11, figs. 6a-6c, $7 \mathrm{a}-7 \mathrm{c}$.

This is a rather common but small species. The septa are less oblique than figured by Brotzen. Otherwise, however, our specimens are in good agreement with the drawings by Brotzen (1936, pl. 162, text fig. 59). (Santonian-Maestrichtian.)

\section{Globorotalites spineus (Cushman) \\ (Plate 7, Figs. 20 and 21)}

Truncatulina spinea Cushman, 1926, p. 22, pl. 2, fig. 10 .

This well-defined species occurs rather rarely in Core 7 and Core 10 , but is always very well preserved. (Santonian-Maestrichtian.)

\section{Glomospira charoides (Jones and Parker)}

(Plate 1, Fig. 18)

Trochammina squamata Jones and Parker var. charoides Jones and Parker, 1860, p. 304.

G. charoides (Jones and Parker), Cushman, 1918, p. 100, pl. 36, figs. 10-15.

This species occurs in all samples except those from Core 10. (Carboniferous-Recent.)

\section{Glomospira corona Cushman and Jarvis} (Plate 1, Fig. 19)

G. charoides (Jones and Parker) var. corona Cushman and Jarvis, 1928, p. 89, pl. 12, figs. 9-11.

This species could be just a further growth stage of $G$. charoides, and thus synonymous. (Upper Cretaceous-Paleogene.)

\section{Glomospira gordialis (Jones and Parker) (Plate 1, Fig. 20)}

Trochammina squamata Jones and Parker, var. gordialis Jones and Parker, 1860, p. 304.

G. gordialis (Jones and Parker), Cushman, 1918, p. 99, pl. 36, figs. 7-9. In this species we include all irregularly coiled tubes of Glomospira. (Carboniferous-Recent.) 


\section{Glomospira gordialis diffundens Cushman and Renz}

(Plate 1, Fig. 21)

G. gordialis (Jones and Parker) var. diffundens, Cushman and Renz, 1946 , p. 15 , pl. 1, fig. 30.

The tendency to become planispiral is obvious. This species fits into the evolutionary lineage beginning with $G$. gordialis and ending with Glomospirella grzybowskii (Troester, in prep.). Whether the ancestor Glomospirella gaultina (Berthelin) is an older synonym of this subspecies or not needs more material for investigation. (Upper Cretaceous-Paleogene.)

\section{Glomospira? irregularis (Grzybowski) \\ (Plate 1, Fig. 22)}

Ammodiscus irregularis Grzybowski, 1898, p. 285, pl. 11, figs. 2 and 3. G. irregularis (Grzybowski), Glaessner, 1937, p. 359, pl. 1, fig. 7.

G. irregularis (Grzybowski), Geroch, 1960, p. 126, pl. 4, fig. 9, (not fig. 10).

Irregularly coiled tube with a rough surface. This species is easily separated from the finely agglutinated $G$. gordialis (Jones and Parker) by its roughness and the larger diameter of the tube. Whether the coarse agglutination is a typical morphological feature compared with other known species of Glomospira is uncertain; it therefore may belong to the genus Tolypammina. (Cretaceous-Paleogene.)

\section{Glomospira serpens (Grzybowski)}

(Plate 1, Fig. 23)

Ammodiscus serpens Grzybowski, 1898, p. 285, pl. 10, figs. 31 , 32 and 33.

G. serpens (Grzybowski), Geroch, 1960, p. 126, pl. 4, fig. 13.

One specimen present in our samples can be assigned to $G$. serpens. (Upper Cretaceous-Paleogene.)

\section{Glomospirella grzybowskii (Jurkiewicz)}

(Plate 1, Fig. 24)

Glomospira grzybowskii Jurkiewicz, 1960, p. 342, pl. 38, fig. 7.

Glomospira grzybowskii Jurkiewicz, Jurkiewicz, 1967, p. 60, pl. 2, fig. 13.

Glomospirella sp., Miller et al., 1982, p. 20, pl. 1, figs. 16 and 17. Glomospirella grzybowskii may represent the end form of an evolutionary lineage beginning with Glomospira gordialis and Glomospira gordialis diffundens. In our samples the three listed species are readily distinguishable. (Upper Cretaceous-Paleogene.)

\section{Guttulina cuspidata Cushman and Ozawa}

$$
\text { (Plate 5, Fig. 3) }
$$

G. adhaerens (Olszewsski) var. cuspidata Cushman and Ozawa, 1930, p. 37 , pl. 6 , fig. 6 .

G. cuspidata Cushman and Ozawa, Sliter, p. 78, 1968, pl. 10, fig. 5. Very rare and rather badly preserved, as are most specimens from Section 9,CC and below. (Upper Cretaceous-Paleogene.)

\section{Gyroidina beisseli White}

(Plate 7, Figs. 1 and 2)

G. beisseli White, 1928b, p. 291, pl. 39, fig. 7 .

A rather scarce species in most samples; often heavily destroyed by boring organisms. (Santonian-Maestrichtian.)

\section{Gyroidina noda Belford}

(Plate 7, Figs. 3-5)

G. noda Belford, 1960, p. 79, pl. 21, figs. 16 and 17 .

Only a few specimens were found, in Core 7. (Santonian-Maestrichtian.)

\section{Gyroidina sp.}

(Plate 7, Figs. 6-8)

This type of Gyroidina is common and well preserved in all samples from Core 7. The aperture, which is slit-like from the umbilicus to the periphery, and the oblique suture on the spiral side, differ from other species of this genus.

\section{Haplophragmoides biumbilicalis Krasheninnikov}

(Plate 2, Figs. 13-18)

H. biumbilicalis Krasheninnikov, 1973, p. 214, pl. 1, figs. 3 and 4.

This species is highly variable, with a transition to the genus Trochamminoides. In our material, there are more evolute tests than figured by Krasheninnikov. However, we prefer to place involute as well as more evolute specimens into the genus Haplophragmoides, rather than into Trochamminoides. (Santonian-Maestrichtian.)

\section{Haplophragmoides fraudulentus Krasheninnikov} (Plate 2, Figs. 19 and 20)

H. fraudulentus Krasheninnikov, 1973, p. 207, pl. 1, figs. 9a-9b.

H. fraudulentus Krasheninnikov, 1974, p. 634, pl. 1, figs. 1a, 1b, $2 \mathrm{a}$.

The tests are relatively small, and the chambers are typically globular. (Santonian-Maestrichtian.)

\section{Haplophragmoides incredibilis Krasheninnikov}

(Plate 2, Fig. 21)

H. incrediblis Krasheninnikov, 1974, p. 636 , pl. 2, figs. 5a-5c.

Typical for this rare species from Hole 543A are the curved sutures and the lobate periphery. (Upper Cretaceous.)

\section{Haplophragmoides linki Nauss}

(Plate 2, Fig. 22)

H. linki Nauss, 1947, p. 339, pl. 49, fig. 7.

H. linki Nauss, Krasheninnikov, 1974 , p. 635 , pl. 1 , figs. $7 \mathrm{a}$ and $7 \mathrm{~b}$. Only one specimen of this species has been found in sediment from Hole 543A. (Upper Cretaceous.)

\section{Haplophragmoides menitens Krasheninnikov}

(Plate 3, Figs. 1 and 2)

H. menitens Krasheninnikov, 1974, p. 636, pl. 2, figs. 3 and 4.

Specimens from our material exhibit more chambers per whorl (up to six chambers) than those figured by Krasheninnikov. We consider them to be conspecific because of their common gross morphology. (Upper Cretaceous.)

\section{Haplophragmoides molestus Krasheninnikov}

(Plate 3, Figs. 3 and 4)

H. molestus Krasheninnikov, 1973, p. 208, pl. 1, figs. $8 \mathrm{a}$ and $8 \mathrm{~b}$. ?"Haplophragmoides” sp., Miller et al., 1982, p. 21, pl. 2, fig. 8.

This finely agglutinated species is probably identical to that from Site 112 figured by Miller et al. (1982). It is relatively abundant at Hole 543A. (Santonian-Maestrichtian.)

\section{Haplophragmoides perexplicatus Krasheninnikov (Plate 3, Fig. 5)}

H. perexplicatus Krasheninnikov, 1973, p. 208, pl. 1, figs. $6 \mathrm{a}$ and $6 \mathrm{~b}$. This species is separated from the larger $H$. constrictus (larger than $0.3 \mathrm{~mm}$ ) mainly by its test diameter (up to $0.17 \mathrm{~mm}$ ). Our specimens are smaller than those described by Krasheninnikov (larger than $\mathbf{0 . 2 2}$ $\mathrm{mm}$ ). (Santonian-Maestrichtian.)

\section{Haplophragmoides cf. walteri (Grzybowski) (Plate 3, Fig. 6)}

Trochammina walteri Grzybowski, 1898, p. 290, pl. 11, fig. 31 .

The tests of this species are typically compressed. They are found in the same condition worldwide. In our samples there are specimens in various degrees of compression; even totally uncompressed individuals were encountered. These latter specimens show some similarities with uncompressed specimens of, for example, $H$. molestus Krasheninnikov.

\section{Hedbergella holmdelensis Olsson}

(Plate 8, Figs. 20 and 21)

H. holmdelensis Olsson, 1964, pp. 160-161, pl. 1, figs. 1 and 2 .

The illustrated specimens are the only planktic foraminifers found in material from Hole 543A. (Campanian-Maestrichtian.) 


\section{Hemisphaerammina batalleri Loeblich and Tappan}

(Plate 1, Fig. 17)

H. batalleri Loeblich and Tappan, 1957, p. 224, pl. 72, fig. 3.

Individual spheres without recognizable aperture. Test rather finely agglutinated. This specimen from Hole $543 \mathrm{~A}$ is in good agreement with the species from the upper Santonian described by Loeblich and Tappan (1957).

\section{Hormosina ovuloides (Grzybowski)} (Plate 2, Fig. 6)

Reophax ovuloides Grzybowski, 1901, p. 223, pl. 8, fig. 3.

the gross morphology shows a more elongated, egg-shaped outline than in $H$. ovulum. It might be possible to include these fragments into Reophax velascoensis. (Upper Cretaceous.)

\section{Hormosina ovulum (Grzybowski)}

(Plate 2, Fig. 7)

Reophax ovulum Grzybowski, 1896, p. 276, pl. 8, figs. 19-21. H. ovulum (Grzybowski), Krasheninnikov, 1974, p. 644, pl. 7, fig. 12. This species is widely described and easily distinguishable from other species by its very smooth surface. (Cretaceous-Paleogene.)

\section{Hormosina ovulum crassa Geroch}

(Plate 2, Figs. 8 and 9)

H. ovulum crassa Geroch, 1966, p. 439, figs. $6(19,21-26)$ and 7 (21-23).

This species is represented by two types, finely and coarsely agglutinated. Specimens are distinguished from $H$. ovulum mainly by the thicker parts. There is a certain similarity to the recent species Reophax guttifer Brady. (Barremian-Maestrichtian.)

\section{Hyperammina dilatata Grzybowski (Plate 1, Figs. 7-9)}

H. dilatata Grzybowski, 1896, p. 274, pl. 8, figs. $17 \mathrm{a}$ and $17 \mathrm{~b}$. H. dilatata Grzybowski, Jurkiewicz, 1967, p. 43, pl. 1, fig. 14 Tubes often have compressed proloculus. The adjacent second chamber was regularly spaced spherical swellings. Fractured pieces without proloculus are similar to Hyperammina excelsa Dylazanka. The latter, however, has a smooth surface. (Upper Cretaceous-Paleogene.)

\section{Hyperammina cf. dilatata Grzybowski}

(Plate 1, Figs. 10 and 11)

Coarsely agglutinated tubes ith constrictions and widenings at regular intervals; sometimes slightly curved.

\section{Hyperammina ex gr. elongata Brady}

(Plate 1, Figs. 12 and 13)

H. ex gr. elongata Brady, Krasheninnikov, 1974, p. 644, pl. 7, figs. 13 and 14.

Test finely agglutinated. The proloculus is not as clearly separated from the test as pictured by Krasheninnikov (1974). Fragments without proloculus can easily be mistaken as tubes of Bathysiphon. Here they are combined as $H$. ex gr. elongata, since tubes with and without proloculus are of similar agglutination and size.

\section{Kalamopsis grzybowskii (Dylazanka)}

(Plate 2, Figs. 3-5)

Hyperammina grzybowskii Dylazanka, 1923, p. 65.

H. sp. aff. subnodosiformis Grzybowski, 1901, p. 264, pl. 7, fig. 5.

The test of this cosmopolitan species is finely agglutinated and partially compressed; only fragments of this species were found. (Upper Cretaceous-Paleogene.)

\section{Labrospira inflata Krasheninnikov (Plate 3, Fig. 7)}

L. inflata Krasheninnikov, 1974, p. 637, pl. 2, figs. 6a, 6b, 7b. Test finely agglutinated, with almost spherical outline. This species is found together with Praecystammina globigeriniformis Krasheninnikov in Hole 543A, whereas at Site 261 it occurs together with $\mathrm{Ha}$ plophragmium lueckei Cushman and Hedberg (1971) only. (SantonianMaestrichtian.)

\section{Labrospira pacifica Krasheninnikov}

(Plate 3, Fig. 8)

L. pacifica Krasheninnikov, 1973, p. 209, pl. 2, figs. 4a, 4b, 5a, 5b.

L. pacifica Krasheninnikov, Gradstein and Berggren, 1981, p. 260, pl. 9 , figs. 9 and 10.

Test rather finely agglutinated. The chambers are more arched than in L. inflata. (Santonian-Maestrichtian.)

\section{Lagena aff. sulcata (Walker and Jacob) (Plate 5, Figs. 1 and 2)}

Serpula (Lagena) sulcata Walker and Jacob, 1798, p. 63, pl. 14, fig. 5.

Only very few specimens of this highly varying species occur in some samples of Core 7. Our specimens show some similarities to $L$. amphora Reuss and $L$. paucicosta Franke, but none shows the apical spine.

\section{Nuttallinella florealis (White)}

(Plate 6, Figs. 1-3)

Gyroidina florealis White, 1928b, p. 293, pl. 40, fig. 3.

Very scarcely distributed in "calcareous" samples of Core 7. (Santonian-Paleocene.)

\section{Osangularia cordieriana (d'Orbigny)}

(Plate 7, Figs. 9 and 10)

Rotalina cordieriana d'Orbigny, 1840, p. 33, pl. 3, figs. 9-11.

This species is very widely distributed in all samples, and occurs in all stages of preservation. Especially in samples with poor preservation (e.g., 7-3, 84-85 cm), fragments of the hyaline umbilical parts are present. (Santonian-Maestrichtian.)

\section{Osangularia whitei (Brotzen) \\ (Plate 7, Figs. 11-15)}

Eponides whitei Brotzen, 1936, pp. 167-169, pl. 12, figs. 5-8c

This species seems to be closely related to $O$. cordieriana, as Brotzen noticed. Most specimens lack a prominent hyaline umbo, in contrast with $O$. cordieriana. (Santonian-Maestrichtian.)

\section{Paratrochamminoides conglobatus (Brady)}

(Plate 3, Fig. 9)

Trochammina conglobata Brady, 1884, p. 341 , pl. 40 , figs. 8 and 9.

It seems justified to assign this form to the recent species $P$. conglobatus because of its morphological similarity, although size is different. (Upper Cretaceous-Recent.)

\section{Paratrochamminoides intricatus Krasheninnikov} (Plate 3, Figs. 10 and 11)

P.(?) intricatus Krasheninnikov, 1973, p. 212, pl. 3, figs. 2a-2c.

Tests irregularly coiled, with globular chambers. Surface finely agglutinated. (Santonian-Maestrichtian.)

\section{Paratrochamminoides semipellucidus Krasheninnikov} (Plate 3, Figs. 12-14)

P.(?) semipellucidus Krasheninnikov, 1973, p. 22, pl. 3, fig. 4.

Chambers elongated, with indistinct sutures. Some tests are more coarsely agglutinated than those from Site 196 described by Krasheninnikov. (Santonian-Maestrichtian.)

\section{Paratrochamminoides vitreus Krasheninnikov} (Plate 3, Figs. 15 and 16)

P.(?) vitreus Krasheninnikov, 1973, p. 212, pl. 3, figs. 1a-1c.

Chambers globular, with distinctive sutures. The number of chambers is smaller than is speciemns from Site 260 figured by Krasheninnikov. $P$ ? corpulentus, which closely resembles the discussed species, has not been found in our material. (Upper Cretaceous.)

\section{Paratrochamminoides sp. 1 \\ (Plate 3, Fig. 17)}

Irregularly coiled tests with compressed chambers. These forms are only found in Section 6,CC. They are comparable to $P$. irregularis (White). 


\section{Paratrochamminoides sp. 2}

(Plate 3, Fig. 18)

Paratrochamminoides sp. Miller, 1982, p. 21, pl. 2, fig. 10.

This type is very comparable to the figured specimen from Site 112 (Labrador Sea).

\section{Plectina aff. conversa (Grzybowski)}

(Plate 4, Fig. 24)

P. aff. conversa (Grzybowski), Krasheninnikov, 1974, p. 643, pl. 7, figs. 3 and 4.

Only a few specimens, probably juveniles, were found in our samples. (Upper Cretaceous.)

\section{Plectorecurvoides parvus Krasheninnikov}

(Plate 4, Fig. 4)

P. parvus Krasheninnikov, 1973, p. 210, pl. 2, figs. 6a-7c.

Our specimens are more comparable to those from Site 260 than to those from Sites 196 and 198 (Hole 198A). (Santonian-Maestrichtian.)

\section{Plectorecurvoides rotundus Krasheninnikov}

(Plate 4, Fig. 5)

P. rotundus Krasheninnikov, 1974 , p. 641 , pl. 5, figs. $4 \mathrm{a}-4 \mathrm{c}, 5 \mathrm{c}$, and $6 \mathrm{c}$. In contrast with $P$. parvus, which shows a globular last chamber, $P$. rotundus has an elongated, flat last chamber and a slit-like aperture. (Aptian-Maestrichtian.)

\section{Plectorecurvoides sp. \\ (Plate 4, Figs. 6 and 7)}

Test flattened and trochospiral; the umbilical side shows 10-12 chambers with oblique sutures; umbilicus prominent; the spiral side shows 2.5 whorls; the halfmoon-like aperture is positioned at the periphery.

\section{Pleurostomella nitida Morrow}

(Plate 6, Fig. 6)

P. nitida Morrow, 1934 , p. 196, pl. 30, figs. 22a and 22b.

P. nitida Morrow, Cushman, 1946, p. 132, pl. 54, fig. 24 .

We found only very few specimens of this rather delicate Turonian species, but it corresponds very well to Cushman's description and figure. (Turonian-Maestrichtian.)

\section{Praebulimina cf. carseyae (Plummer)}

(Plate 5, Fig. 6)

Buliminella carseyae Plummer, 1931, p. 179, pl. 8, fig. 9.

Only a few specimens were found in Core 7 that show some similarity to $P$. carseyae; the chambers are less elongated than in the type specimen. (Campanian-Maestrichtian.)

\section{Praebulimina cushmani (Sandidge)}

(Plate 5, Fig. 7)

Buliminella cushmani Sandidge, 1932, p. 280, pl. 42, figs. 18 and 19. Specimens of this species show typically inflated chambers and a rather tapering embryonal part. Most common in all "calcareous" samples. (Santonian-Maestrichtian.)

\section{Praebulimina reussi (Morrow)}

(Plate 5, Fig. 9)

Bulimina reussi Morrow, 1934, p. 195, pl. 29, fig. 12.

Major constituent in all "calcareous" samples, together with $P$. cushmani; mostly well preserved, except in Core 10. (Santonian-Maestrichtian.)

\section{Praebulimina sp.}

(Plate 5, Fig. 8)

This species occurs in Cores 9 and 10 only. The chambers are separated by low-angled sutures, and the aperture is an arched slit at the base of the last chamber, therefore rather umbilically positioned. (Campanian?.)

\section{Praecystammina globigerinaeformis Krasheninnikov}

(Plate 4, Fig. 8)

P. globigerinaeformis Krasheninnikov, 1973, p. 210, pl. 2, figs. 1a-1c, 2.

P. globigerinaeformis Krasheninnikov, Gradstein and Berggren, 1981, p. 258, pl. 9, figs. 11-15.

Cystammina globigerinaeformis Krasheninnikov, Miller et al., 1982, p. 21, pl. 2, figs. 13, 17, 21 .

This species, first described by Krasheninnikov, is geographically and stratigraphically widespread. (Santonian-Paleogene.)

\section{Pseudospiroplectinata compressiuscula (Chapman)}

(Plate 4, Fig. 18)

Bigenerina compressiuscula Chapman, 1917, p. 19, pl. 2, figs. 13 and 14.

P. compressiuscula (Chapman), Sliter, 1977b, p. 680, pl. 3, fig. 1.

Few specimens were found. (Upper Cretaceous.)

Pseudobolivina cuneata Krasheninnikov

(Plate 4, Fig. 2)

P. cuneata Krasheninnikov, 1974 , p. 639 , pl. 4, figs. 8a, 8b, 9a.

Few specimens were found in Hole 543A. This species can be separated from $P$. munda by its increase in size and by the higher additional chambers. (Upper Cretaceous.)

\section{Pseudobolivina munda Krasheninnikov} (Plate 4, Fig. 3)

P. munda Krasheninnikov, 1973, p. 210, pl. 2, figs. 10 and 11 .

This species was found only in Section 7,CC and Cores 8 and 9. (Santonian-Maestrichtian.)

\section{Pullenia coryelli White \\ (Plate 6, Figs. 13 and 14)}

P. coryelli White, 1929, p. 56 , pl. 5 , fig. 22 .

This is a rather scarce species in samples from Core 7. (Campanian-Paleocene.)

\section{Pullenia cretacea Cushman}

(Plate 2, Figs. 15 and 16)

P. cretacea Cushman, 1936, p. 75 , p. 13 , fig. 8 .

A scarcely distributed species, but typical for Core 7. (SantonianMaestrichtian.)

\section{Reophax scalaris Grzybowski}

(Plate 2, Figs. 10 and 11)

R. guttifera Brady var. scalaria Grzybowski, 1896, p. 277, pl. 8, figs. $26 \mathrm{a}-26 \mathrm{~b}$.

R. scalaria Grzybowski, Liszka and Liszkowa, 1981, p. 168, pl. 1 , fig. 15 .

There are two variants of this species. Specimens occurring in Cores 5 and 6 are compressed. They correspond to those described by Grzybowski. In Sections 7-1 through 10-1 the tests are unaltered. The high variability of the external morphology is correlated with the degree of preservation, as discussed by Liszka and Liszkowa (1981). (Upper Cretaceous-Paleogene.)

\section{Reophax velascoensis (Cushman) (Plate 2, Fig. 12)}

Nodosinella velascoensis Cushman, 1926, p. 583, pl. 20, figs. 9a-9b. Nodellum velascoense (Cushman), Glaessner, 1937, p. 358, pl. 1, fig. 6.

Nodellum velascoense (Cushman), Sandulescu, 1973, p. 21, pl. 1, figs. 16.

A common species in flysch-type deposits. In Hole 543A it only occurs from Section 6,CC upward. (Upper Cretaceous-Paleogene.)

\section{Reussella cf. pseudospinulosa Troelsen (Plate 5, Fig. 18)}

$R$. pseudospinulosa Troelsen, 1937, S. 260, (nomen nudum) $R$. pseudospinulosa Troelsen, Brotzen, 1945, p. 46, pl. 1, fig. 6 . 
The specimen illustrated here resembles very closely $R$. pseudospinulosa, but is more compact and shorter. The spiny edges are less pronounced than those figured by Hofker (1957, p. 212, Abb. 259). All Leg 78 specimens are very well preserved and rather common. (Campanian-Maestrichtian.)

\section{Reussella szajnochae (Grzybowski) (Plate 5, Fig. 19)}

Verneuilina szajnochae Grzybowski, 1896, p. 287, pl. 9, fig. 19.

$R$. szajnochae occurs well preserved in samples from Cores 7 and 9; none were observed in Core 10. (Upper Santonian-Maestrichtian.)

\section{Rhabdammina subdiscreta Grzybowski}

(Plate 1, Figs. 1 and 2)

R. subdiscreta Grzybowski, 1896, p. 275, pl. 8, figs. 5 and 6 .

Straight tubes with constrictions. Tests rather coarsely agglutinated, surface rough. (Upper Cretaceous-Paleogene.)

\section{Rhabdammina div. sp. \\ (Plate 1, Figs. 3-5)}

Specimens with thick-walled tubes are often described as $R$. $a b y$ ssorum (Sars, 1869), and the slimmer and thin-walled specimens are separated as $R$. linearis (Brady, 1879). Our specimens show rough surfaces without any constrictions, local thickenings, or bends (see Tolypammina). Our material does not allow any taxonomic decisions, so we have described these forms in open nomenclature. The thick-walled tubes are up to $0.5 \mathrm{~mm}$ long and have a diameter of $0.12 \mathrm{~mm}$; thin tubes measure up to $8.3 \mathrm{~mm}$ long and have a $0.05 \mathrm{~mm}$ diameter.

\section{Rhizammina ex gr. algaeformis Brady (Plate 1, Fig. 6)}

R. algaeformis Brady, 1879, p. 20, pl. 4, figs. 16 and 17.

Branched tubes with diameters up to $0.03 \mathrm{~mm}$. The surface is rough and coarsely agglutinated.

\section{Saccammina grzybowskii (Schubert)}

(Plate 1, Fig. 14)

Reophax grzybowskii Schubert, 1902, p. 20, pl. 1, figs. 13a-13b.

Test spherical with a wide elongated aperture. This species name established by Schubert is not commonly used. More often these specimens are named $S$. complanata (Franke, 1912). Whether $S$. complanata and $S$. grzybowskii (Schubert) are truly synonymous remains open. (Upper Cretaceous-Paleogene.)

\section{Saccammina sphaerica Sars}

(Plate 1, Fig. 15)

S. sphaerica M. Sars, 1872 , p. 250 .

S. sphaerica M. Sars, Carpenter, 1875, p. 532, pl. 272a-272c.

S. complanata (Franke), Krasheninnikov, 1974, p. 644, pl. 7, figs. 10a$10 \mathrm{~b}$.

Test spherical with a single aperture, rather coarsely agglutinated, but the surface is coated with a thin veneer. A confusion with the initial stage of Hormosina ovulum is impossible because of the difference in agglutination. The specimens from Hole 543A can be included in the recent species $S$. sphaerica because of morphological similarities. (Upper Cretaceous-Recent.)

\section{Spiroplectammina dentata (Alth)}

(Plate 3, Fig. 20)

Textularia dentata Alth, 1850, p. 262, pl. 13, fig. 13.

This species is characterized by its dentated outline and the straight sutures, contrasted with the curved sutures of $S$. subhaeringensis. (Turonian-Paleocene.)

\section{Spiroplectammina subhaeringensis (Grzybowski)}

(Plate 3, Figs. 21-23)

Textularia subhaeringensis Grzybowski, 1896, p. 285, pl. 9, figs. 16 and 13.

S. subhaeringensis (Grzybowski), Liszka and Liszkowa, 1981, p. 178, pl. 3 , figs. 6 and 7 .
A rare to common species in all "calcareous" samples. A detailed discussion of this species, described from specimens from the Carpathian flysch, has been published by Liszka and Liszkowa (1981). (Upper Cretaceous.)

\section{Tolypammina}

All curved, agglutinated tubes are combined in the genus Tolypammina, resulting in two types: $T$. sp. 1 is thick-walled; the walls of $T$. sp. 2 are much thinner.

\section{Tolypammina sp. 1 \\ (Plate 2, Fig. 1)}

The tests are curved, with a smooth surface. Measurements: length up to $0.45 \mathrm{~mm}$, width to $0.15 \mathrm{~mm}$, wall thickness $0.03 \mathrm{~mm}$.

\section{Tolypammina sp. 2 \\ (Plate 2, Fig. 2)}

The tests are up to $0.4 \mathrm{~mm}$ long, up to $0.08 \mathrm{~mm}$ wide, and have a wall thickness of $0.015 \mathrm{~mm}$. Specimens are curved, with a rough surface. The walls are only half as thick as in $T$. sp. 1 .

\section{Tritaxia aspera (Cushman) \\ (Plate 4, Fig. 19)}

Clavulina trilatera Cushman var. aspera Cushman, 1926, p. 589, pl. 17 , fig. 3.

T. aspera (Cushman), Sliter, 1977a, p. 676, pl. 3, figs. 2-4.

This species was also found at Sites 356 and 357 by Sliter. Our material lacks the large specimens illustrated by Sliter (1977a, p. 00, pl. 3, fig. 2). (Upper Cretaceous.)

\section{Trochamminoides cf. coronatus (Brady)}

(Plate 3, Fig. 19)

Trochammina coronata Brady, 1879, p. 58, pl. 5, fig. 15 .

Mostly compressed tests with larger chambers in the last whorl. This species is well known from flysch areas, and is assigned to the recent species Trochamminoides coronatus. In Hole 543A it occurs only in the upper part, down to Core 6.

\section{Trochammina gyroidinaeformis Krasheninnikov (Plate 4, Figs. 11-13)}

T. gyroidinaeformis Krasheninnikov, 1974, p. 641 , pl. 5, figs. 7a-7c, $8 \mathrm{a}-8 \mathrm{c}, 9 \mathrm{c}$.

Very scarce, found in only a few samples. This is in contrast with Krasheninnikov's findings. (Upper Cretaceous.)

\section{Trochammina insueta Krasheninnikov}

(Plate 4, Fig. 14)

T. insueta Krasheninnikov, 1974 , p. 642 , pl. 6, figs. 6a-6c.

Only one specimen was found in our material from Hole 543A. This species was described by Krasheninnikov as a member of the Haplophragmium lueckei assemblage (lower assemblage). In our samples it occurs together with Praecystammina globigerinaeformis Krasheninnikov (Krasheninnikov's upper assemblage). (Upper Cretaceous.)

\section{Trochammina ex gr. globigeriniformis (Parker and Jones) (Plate 4, Figs. 9 and 10)}

Lituola nautiloidea Lamarck var. globigeriniformis Parker and Jones, 1865 , p. 407 , pl. 15 , figs. 46 and 47 ; pl. 17, figs. 96-98.

The test is trochospirally coiled, with a coarse agglutination. The umbilical side exhibits three chambers with an arched aperture. Specimens with this morphology may be placed close to the recent species T. globigeriniformis.

\section{Uvigerinammina jankoi Majzon}

(Plate 4, Fig. 20)

U. jankoi Majzon, 1943, p. 158, pl. 2, figs. 15a-15b.

U. jankoi Majzon, Krasheninnikov, 1974, p. 642, pl. 6, figs. 9a-9b, 10a.

U. jankoi Majzon, Krasheninnikov and Pflaumann, 1977, p. 569, pl. 3 , figs. 12 and 13 . 
The finely agglutinated form resembles Krasheninnikov's specimens (Site 260) more than the coarsely agglutinated forms from Sites 367 and 368. (Cenomanian-Maestrichtian.)

\section{Verneuilina cretacea Karrer}

(Plate 4, Fig. 15)

V. cretacea Karrer, 1870 , p. 164 , pl. 1, fig. 1 .

The test is rather coarsely agglutinated. This fact led to the separation of this species from other Verneuilina species. Krasheninnikov (1974) figured a specimen which was finely agglutinated, quite similar to the calcareous Reussella. It remains open whether these specimens represent juvenile stages of Spiroplectinata compressiuscula (Chapman). (Upper Cretaceous.)

\section{ACKNOWLEDGMENTS}

We wish to thank B. Biju-Duval and C. J. Moore, Co-Chief Scientists on Leg 78A, for the opportunity to join the cruise and to study the interesting material. We also extend our thanks to our colleagues A. Auras, J. Breitinger, R. Hrusa, H. Hüttemann, and M. Spindler, who helped to prepare the manuscripts. Further, we are especially indebted to H. P. Luterbacher for his interest and his critical reading. We also appreciate very much the help of A. Lupke and F. Waible, who typed and corrected the manuscrips. Finally, we would like to express our thanks to the National Science Foundation of the U.S.A. and the DFG of West Germany for funding the project.

\section{REFERENCES}

Beckmann, J. P., 1978. Late Cretaceous smaller benthic foraminiferen from Sites 363 and 364, DSDP Leg 40, southeast Atlantic Ocean. In Bolli, H. M., Ryan, W. B. F., et al., Init. Repts. DSDP, 40: Washington (U.S. Govt. Printing Office), 759-781.

Belford, D. J., 1960. Upper Cretaceous foraminifera from the Toolonga Calcilutite and Gingin Chalk, Western Australia. Bur. Min. Res. Geol. Geophys. Bull., 57:1-198.

Berger, W. H., and Winterer, E. L., 1974. Plate stratigraphy and the fluctuating carbonate line. In Hsü, K. J., and Jenkyns, H (Eds.), Pelagic Sediments on Land and Under the Sea. London (Blackwell Sci. Pubs., Int. Assoc. Sediment.), Spec. Publ., 1:11-48.

Brotzen, F., 1936. Foraminiferen aus dem schwedischen untersten Senon von Eriksdal in Schonen. Sver. Geol. Unders., Ser. C., No. 396: 1-206.

Butt, A., 1981. Depositional environments of the Upper Cretaceous rocks in the northern part of the eastern Alps. Cushman Lab. Foram. Res. Spec. Publ., No. 20:1-121.

Cushman, J. A., 1918. The Foraminifera of the Atlantic Ocean. U.S. Nat. Mus. Bull., 104, Pt. 1:1-114.

1925. Some new foraminifera from the Velasco Shale of Mexico. Cushman Lab. Foram. Res., 1:18-22.

1946. Upper Cretaceous foraminifera of the Gulf Coast region of the United States and adjacent areas. U.S. Geol. Surv. Prof. Paper, 206.

Cushman, J. A., and Jarvis, P. W., 1928. Cretaceous foraminifera from Trinidad. Cushman Lab. Foram. Res., 4:85-102.

1932. Upper Cretaceous foraminifera from Trinidad. Proc. U.S. Nat. Mus., 80:1-60.

Detrick, R. S., Sclater, J. G., and Thiede, J., 1977. The subsidence of aseismic ridges. Earth Planet. Sci. Lett., 34:185-196.

Drooger, C. W., 1952. Foraminifera from Cretaceous-Tertiary transitional strata of the Hodna Mountains, Algeria. Cushman Found. Foram. Res. Contrib., 3, Pt. 2:89-103.

Ellis, B. F., and Messina, A., 1940. Catalogue of Foraminifera. Am. Mus. Nat. Hist. (supplements, post-1940).

Geroch, S., 1960. Microfaunal assemblages from the Cretaceous and Paleogene Silesian unit in the Beskid Slaski Mountains. Inst. Geol. Biul., Vol. 153.

Gradstein, F. M., and Berggren, W. A., 1981. Flysch-type agglutinated foraminfera and the Maestrichtian to Paleogene history of the Labrador and North seas. Mar. Micropaleontol., 6:211-268.

Hanzlikova, E., 1972. Carpathian Upper Cretaceous Foraminiferida of Moravia (Turonian-Maestrichtian). Rozpr. Ustred Ustav. Geol., 39:5-159.
Hofker, J., 1957. Foraminiferen der Oberkreide von Nordwestdeutschland und Holland. Geol. Jb. Beih., No. 27.

Huss, F., 1966. Les foraminifères agglutinants de la série soussilésienne de l'unité pétrolifère de Weglowka. Pol. A. N., Prace Geol., 34:7-76.

Jurkiewicz, H., 1967. Foraminifers in the Sub-Menilitic Palaeogene of the Polish Middle Carpathians: Inst. Geol. Biul., 210:5-102.

Klasz, I. de, 1953. Einige neue oder wenig bekannte Foraminiferen aus der helvetischen Oberkreide der Bayerischen Alpen, südlich Traunstein (Oberbayern). Geol. Bavarica, 17:223-239.

Koch, W., 1971. Biostratigraphie in der Oberkreide und Taxonomie von Foraminiferen. Geol. Jb., 38:3-123.

Krasheninnikov, V. A., 1973. Cretaceous benthonic foraminifera, Leg 20, Deep sea Drilling Project. In Heezen, B. C., MacGregor, I. D., et al., Init. Repts. DSDP, 20: Washington (U.S. Govt. Printing Office), 205-219.

1974. Upper Cretaceous benthonic agglutinated foraminifera, Leg 27 of the Deep Sea Drilling Project. In Veevers, J. J., Heirtzler, J. R., et al., Init. Repts. DSDP, 27: Washington (U.S. Govt. Printing Office), 631-662.

Krasheninnikov, V. A., and Pflaumann, U., 1977. Cretaceous agglutinated foraminifera of the Atlantic Ocean off West Africa (Leg 41, Deep Sea Drilling Project). In Lancelot, Y., Seibold, E., et al., Init. Repts. DSDP, 41: Washington (U.S. Govt. Printing Office), 565-580.

Liszka, S., and Liszkowa, J., 1981. Revision of J. Grzybowski's paper (1896) "Foraminifera of the red clays from Wadowice". Rocz. Polsk. Tow. Geol., 51:153-208.

Loeblich, A. R., and Tappan, H., 1957. Eleven new genera of Foraminifera. U.S. Nat. Mus. Bull., 215:223-232.

1964. Sarcodina, chiefly "Thecamoebians" and Foraminiferida. In Moore, R. C. (Ed.), Treatise on Invertebrate Paleontology, Protista 2, Pt. c, Vol. 1:C1-C510; Vol. 2:C511-C900.

Marie, P., 1941. Les foraminifères de la Crai a Belemnitella mucronata du Bassi de Paris. Mem. Mus. Nat. Hist. Nat., Nouv. Ser., Vol. 12.

Martin, L., 1964. Upper Cretaceous and lower Tertiary foraminifera from Fresno County, California. (Austria) Geol. Bundesanst. Jahrb., Sonderb. 9:1-128.

Miller, K. G., Gradstein, F. M., and Berggren, W. A., 1982. Late Cretaceous to early Tertiary agglutinated benthic foraminifera in the Labrador Sea. Micropaleontology, 28:1-30.

Moore, J. C., Biju-Duval, B., and Leg 78A Shipboard Scientific Party, 1982. Offscraping and underthrusting of sediment at the deformation front of the Barbados Ridge: Deep Sea Drilling Project Leg 78A. Geol. Soc. Am. Bull., 93:1065-1077.

Neagu, T., 1965. Albian foraminifera of the Rumanian Plains. Micropaleontology, 11:1-38.

1968. Biostratigraphy of Upper Cretaceous deposits in the southern Eastern Carpathians near Brasov. Micropaleontology, 14: 225-241.

1970. Micropaleontological and stratigraphical study of the Upper Cretaceous deposits between the upper valleys of the Buzau and Riul rivers (Eastern Carpathians). Inst. Geol. Mem., Vol. 12.

Said, R., and Kenawy, A., 1956. Upper Cretaceous and lower Tertiary foraminifera from northern Sinai, Egypt. Micropaleontology, 2: 105-173.

Salaj, J., and Samuel, O., 1966. Foraminiferen der Westkarpatenkreide. Bratislava (Geol. Ustav Dionyza Stura).

Sandidge, J. R., 1932. Foraminifera from the Ripley formation of western Alabama. J. Paleont., 6:265-287.

Sandulescu, J., 1973. Etude micropaleontologique et stratigraphique du flysch du Cretace supérieur Paleocene de la region de BretcuComandau (Secteur intern meridional de la nappe de Tarcau-Carpates orientales). Inst. Geol. Mem., 17:7-12.

Sliter, W. V., 1968. Upper Cretaceous foraminifera from Southern California and northwestern Baja California, Mexico. Univ. of Kan. Paleont. Contrib., 7(49):1-141.

1975. Foraminiferal life and residue assemblages from Cretaceous slope deposits. Geol. Soc. Am. Bull., 86:897-906.

1977a. Cretaceous foraminifers from the southwestern Atlantic Ocean, Leg 36, Deep Sea Drilling Project. In Barker, P. F., Dalziel, I. W. D., et al., Init. Repts. DSDP, 36: Washington (U.S. Govt. Printing Office), 519-573. 
1977b. Cretaceous benthonic foraminifers from the western South Atlantic, Leg 39, Deep Sea Drilling Project. In Supko, P. R., Perch-Nielsen, K., et al., Init. Repts. DSDP, 39: Washington (U.S. Govt. Printing Office), 657-697.

Sliter, W. V., and Baker, R. A., 1972. Cretaceous bathymetric distribution of benthic foraminifers. J. Foram. Res., 2:167-183.

Vasilenko, V. P., 1954. Anomalinidae. Fossil Foraminifera of the U.S.S.R. Vses. Neft. Nauchno-Issled. Geol. Razved. Inst. Trudy, 80:1-282.
White, P., 1928a. Some index foraminifera of the Tampico embayment area of Mexico, pt. 1. J. Paleontol., 2:177-215.

$1928 \mathrm{~b}$. Some index foraminifera of the Tampico embayment area of Mexico, pt. 2. J. Paleont., 2:280-317.

Date of Initial Receipt: February 1, 1983

Date of Acceptance: September 21, 1983 

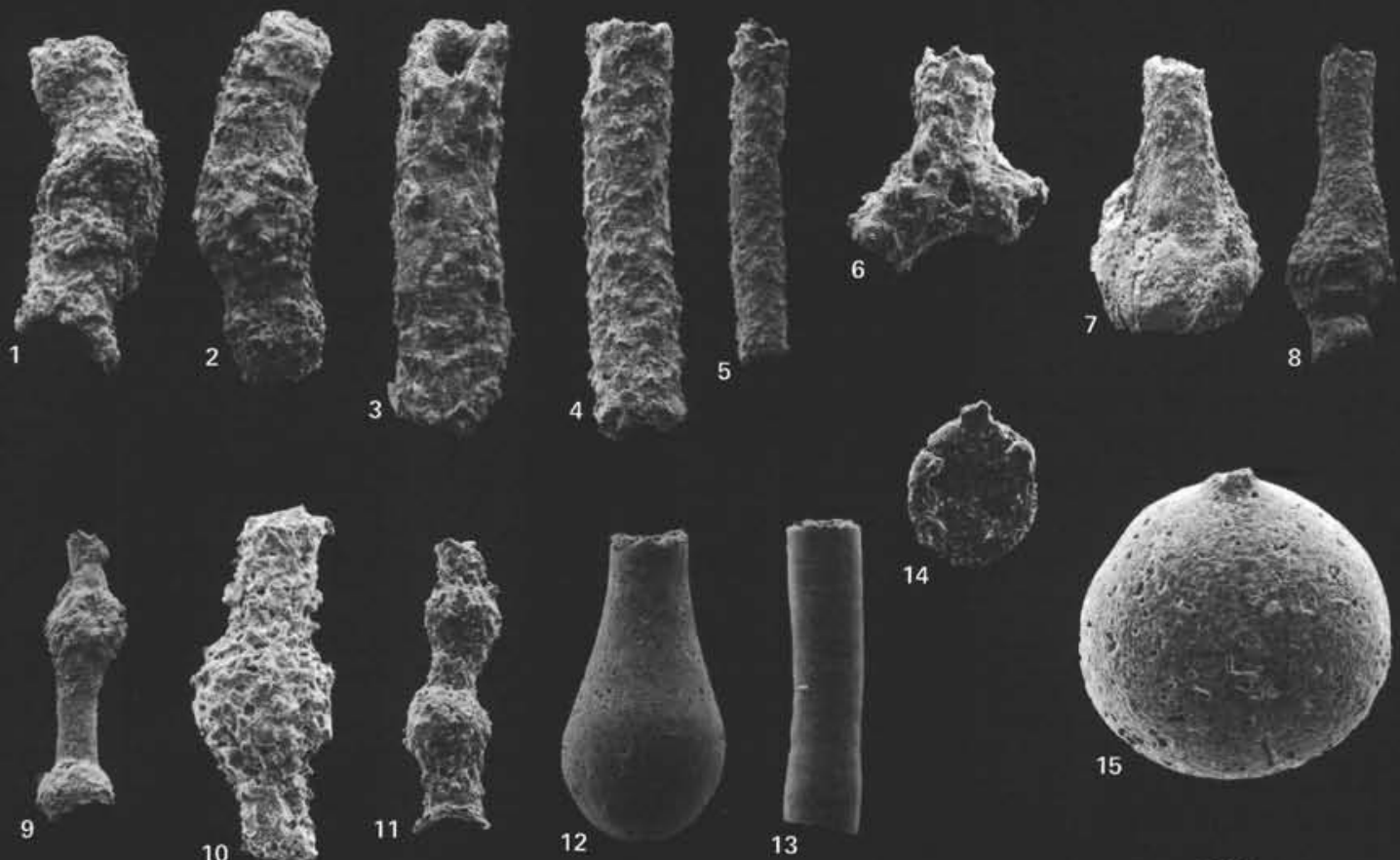

3 axs:
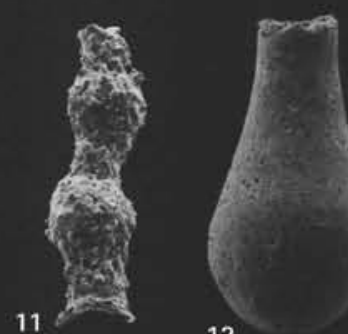

12
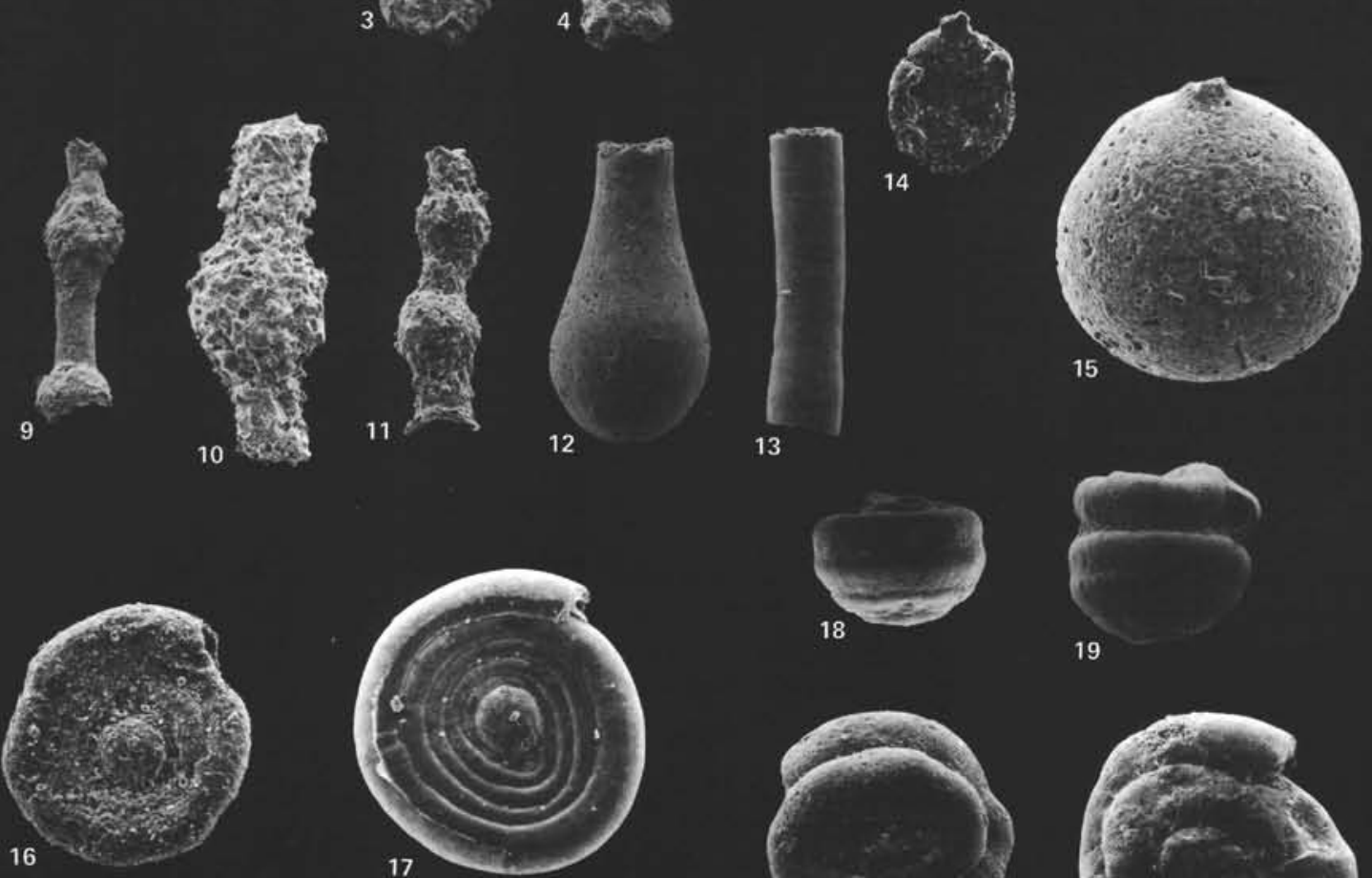

19

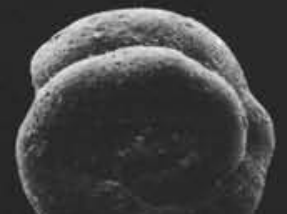

20
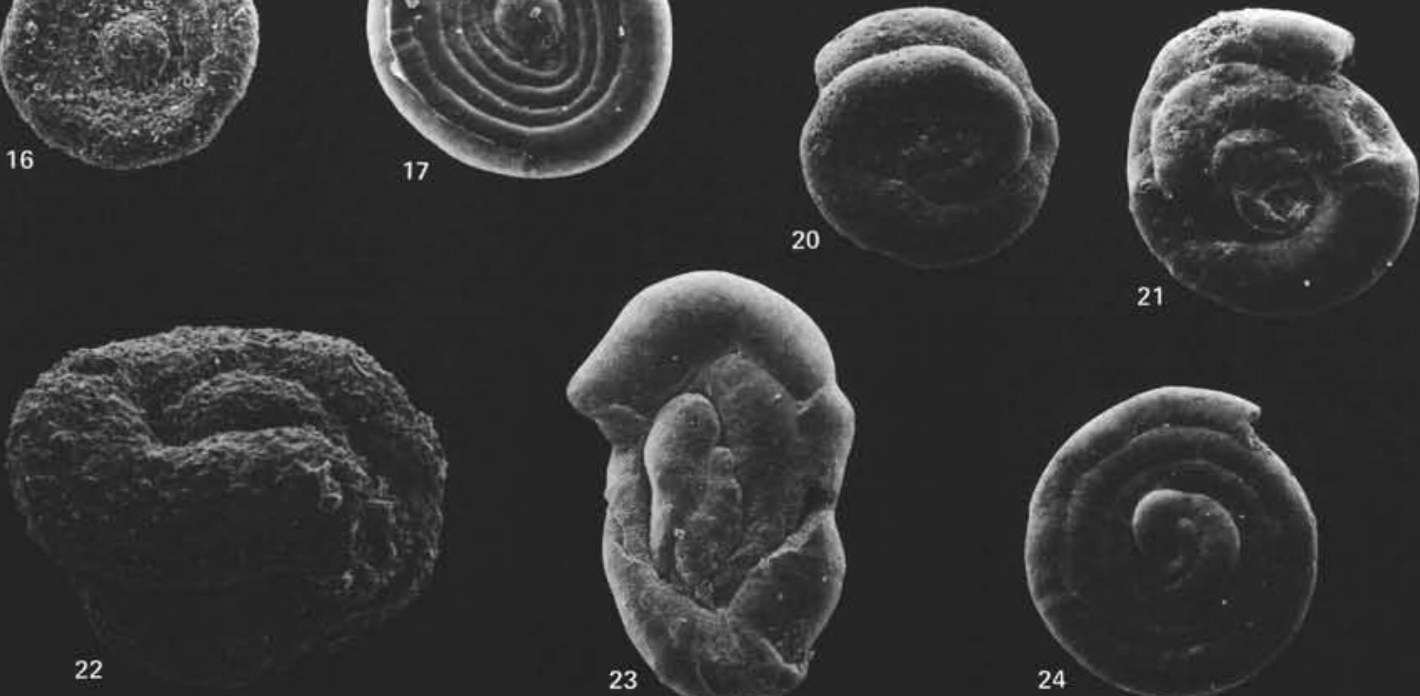

Plate 1. 1, 2. Rhabdammina subdiscreta Grzybowski, (1) $80 \times$, Sample 543A-6-1, 53-55 cm, Neg. 02183, (2) 60×, Sample 543A-7-4, 4-6 cm, Neg. 02020. 3-5. Rhabdammina div. sp., (3) $80 \times$, Sample 543A-7-3, 73-75 cm, Neg. 02014, (4) $120 \times$, Sample 543A-7-3, 73-75 cm, Neg. 02011, (5) $120 \times$, Sample 543A-9,CC, Neg. 02189. 6. Rhizammina ex gr. algaeformis Brady, 160×, Sample 543A-9,CC, Neg. 02188. 7-9. Hyperammina dilatata Grzybowski, 80×, Sample 543A-6,CC, (7) Neg. 02185, (8) Neg. 02186, (9) Neg. 02187. 10, 11. Hyperammina cf. dilatata Grzybowski, 80×, Sample 543A-7-4, 4-6 cm, (10) Neg. 02299, (11) Neg. 02306. 12, 13. Hyperammina ex gr. elongata Brady, 80 $\times$, (12) Sample 543A-7-1, 146-148 cm, Neg. 05298, (13) Neg. 05299. 14. Saccammina grzybowskii (Schubert), 120×, Sample 543A-6-1, 53-55 cm, Neg. 02410. 15. Saccammina sphaerica Sars, $80 \times$, Sample 543A-7-1, 73-75 cm, Neg. 02311. 16. Ammodiscus asperellus Krasheninnikov, $160 \times$, Sample 543A-7-2, 73-75 cm, Neg. 05326. 17. Ammodiscus cretaceous (Reuss), 120×, Sample 543A-7-1, 73-75 cm, Neg. 02322. 18. Glomospira charoides (Jones and Parker), 80×, Sample 543A-7-4, 4-6 cm, Neg. 02316. 19. Glomospira corona Cushman and Jarvis, 80 $\times$, Sample 543A-7-4, 4-6 cm, Neg. 02315. 20. Glomospira gordialis (Jones and Parker), 80×, Sample 543A-7-1, 73-75 cm, Neg. 02400. 21. Glomospira gordialis diffundens Cushman and Renz, 80×, Sample 543A-5-2, 113-115 cm, Neg. 02393. 22. Glomospira? irregularis (Grzybowski), 80 Sample 543A-7,CC, Neg. 02324. 23. Glomospira serpens (Grzybowski), $60 \times$, Sample 543A-6-1, 53-55 cm, Neg. 02320. 24. Glomospirella grzybowskii (Jurkiewicz), 80×, Sample 543A-7-4, 4-6 cm, Neg. 02319. 


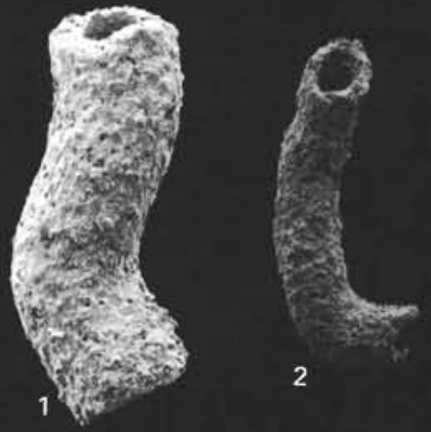

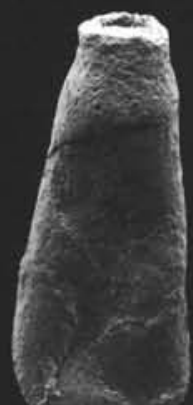

3

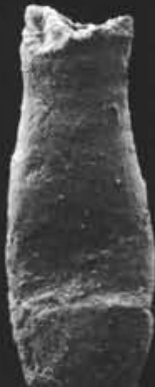

4

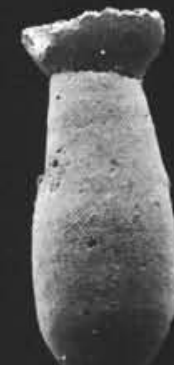

5

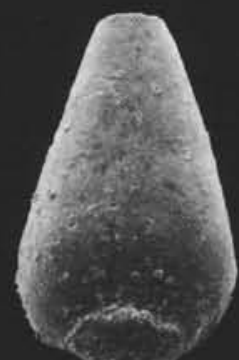

6 in $6 x$
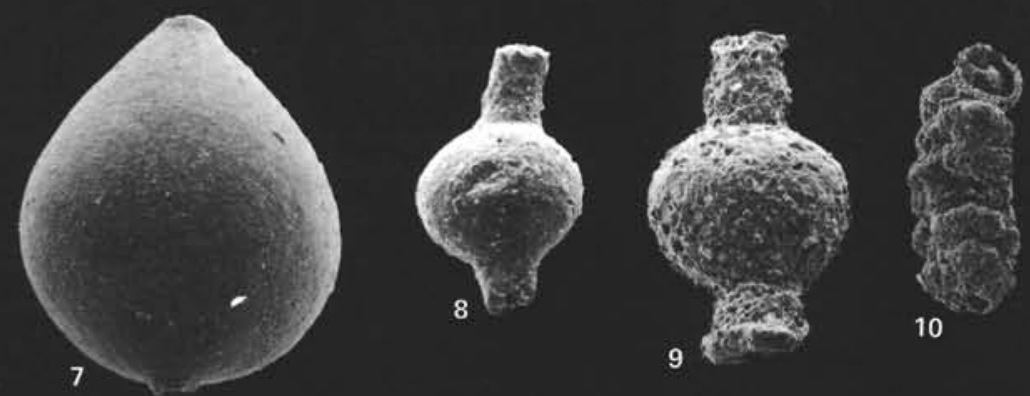

10

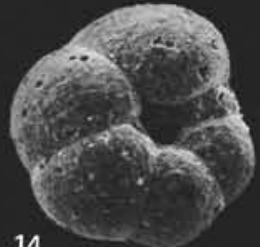

14
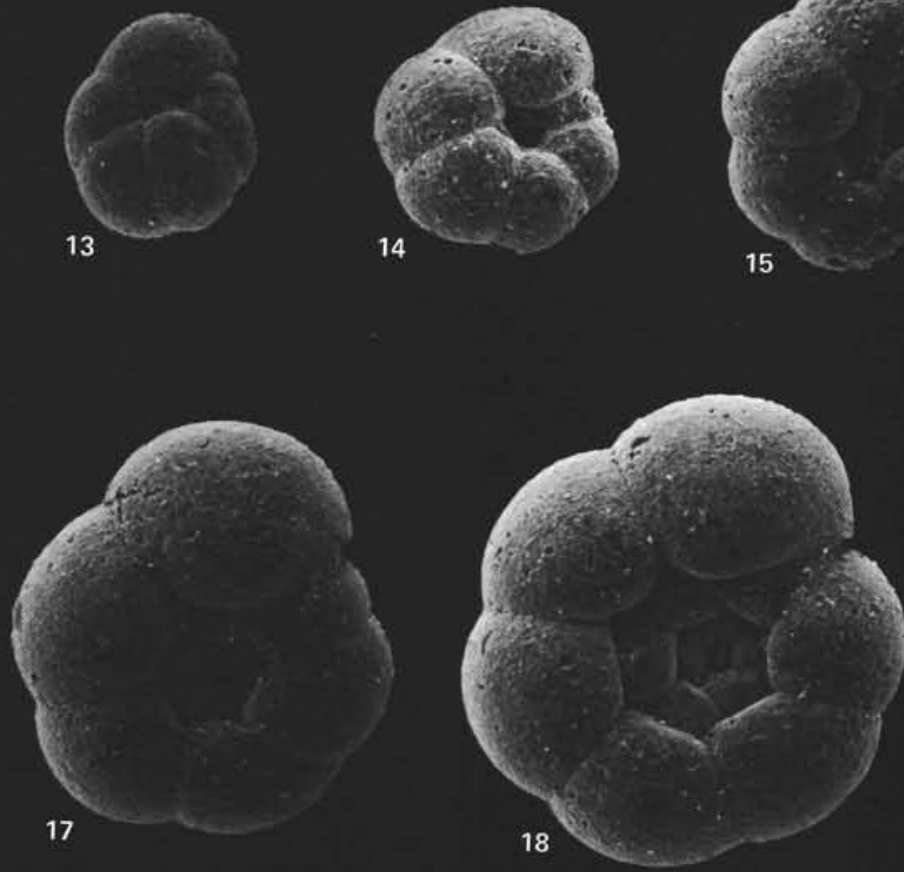

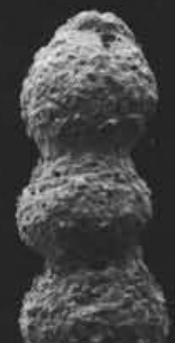

11
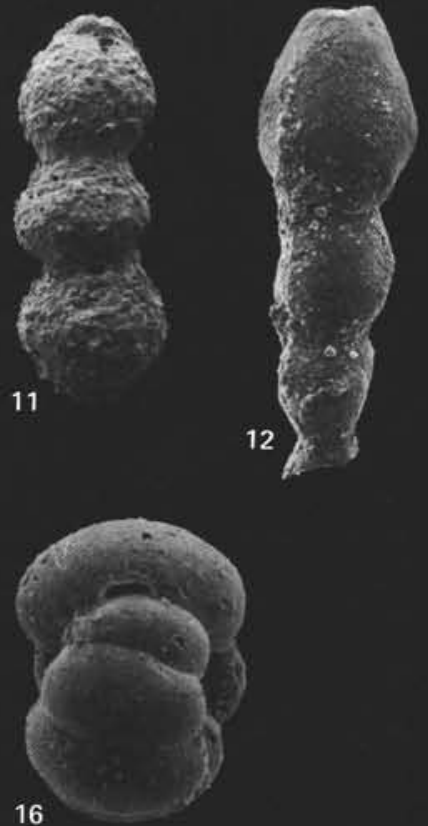

16

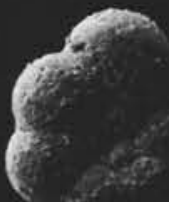

19

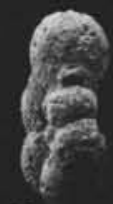

20

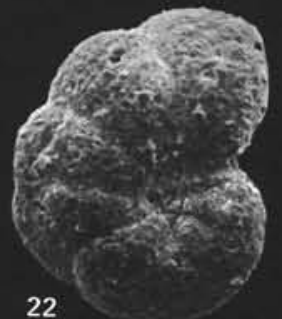

21

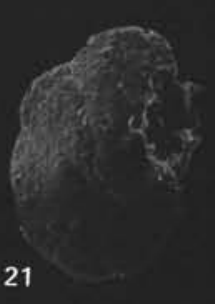

22

Plate 2. 1. Tolypammina sp. 1, 95×, Sample 543A-7-3, 73-75 cm, Neg. 02013. 2. Tolypammina sp. 2, 95×, Sample 543A-7-3, 73-75 cm, Neg. 02015. 3-5. Kalamopsis grzybowskii (Dylazanka), Sample 543A-6-1, 53-55 cm, (3) $95 \times$, Neg. 02180, (4) $95 \times$, Neg. 02179, (5) $95 \times$, Neg. 02182. 6. Hormosina ovuloides (Grzybowski), $140 \times$, Sample 543A-7-3, 73-75 cm, Neg. 02307. 7. Hormosina ovulum (Grzybowski), 140× Sample 543A-7-4, 4-6 cm. Neg. 02303. 8, 9. Hormosina ovulum crassa Geroch, Sample 543A-7-4, 4-6 cm, (8) 140×, Neg. 02304, (9) 95 $\times$, Neg. 02301. 10, 11. Reophax scalaris Grzybowski, $95 \times$ (10) Sample 543A-6-1, 53-55 cm, Neg. 02312, (11) Sample 543A-9-1, 44-46 cm, Neg. 02297. 12. Reophax velascoensis (Cushman), $95 \times$, Sample 543A-6,CC, Neg. 02309. 13-18. Haplophragmoides biumbilicalis Krasheninnikov, 140×, (13) Sample 543A-7-4, 4-6 cm, Neg. 02330, (14) Neg. 02329, (15) Neg. 02328, (16) peripheral view, Neg. 02331, (17) Neg. 02327, (18) Neg. 02326. 19, 20. Haplophragmoides fraudulentus Krasheninnikov, 140 ×, (19) Sample 543A-7-1, 146-148 cm, Neg. 02597, (20) peripheral view, Neg. 02598. 21. Haplophragmoides incredibilis Krasheninnikov, $140 \times$, Sample 543A-7-1, 73-75 cm, Neg. 02354.22 . Haplophragmoides linki Nauss, 140×, Sample 543A-7-1, 146-148 cm, Neg. 02599. 

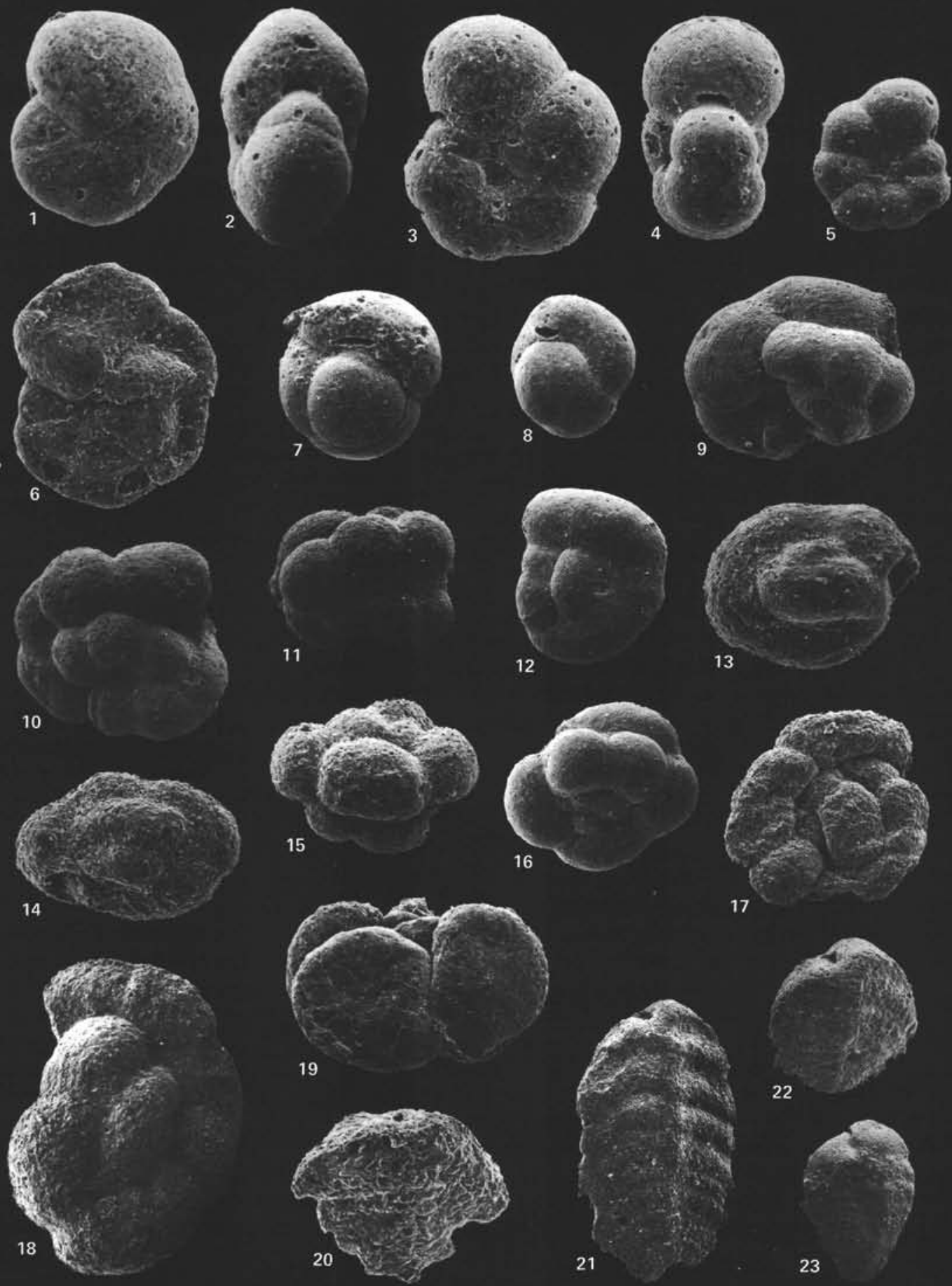

17

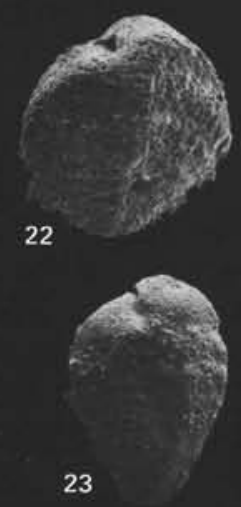

Plate 3. 1, 2. Haplophragmoides menitens Krasheninnikov, $125 \times$, (1) Sample 543A-7-1, 73-75 cm, Neg. 02351, (2) peripheral view, Sample 543A-7-1, 146-148 cm, Neg. 02596. 3, 4. Haplophragmoides molestus Krasheninnikov, 125 $\times$, Sample 543A-7-4, 4-6 cm, (3) Neg. 02332, (4) peripheral view, Neg. 02333. 5. Haplophragmoides perexplicatus Krasheninnikov, 125×, Sample 543A-9-1, 44-46 cm, Neg. 02359. 6. Haplophragmoides cf. walteri (Grzybowski), 125 × , Sample 543A-6-1, 53-55 cm, Neg. 02353. 7. Labrospira inflata Krasheninnikov, 125 ×, Sample 543A-7-1, 146$148 \mathrm{~cm}$, Neg. 02398 . 8. Labrospira pacifica Krasheninnikov, $125 \times$, Sample 543A-7-1, 146-148 cm, Neg. 02399. 9. Paratrochamminoides conglobatus (Brady), 60×, Sample 543A-7-4, 4-6 cm, Neg. 06063. 10, 11. Paratrochmminoides intricatus Krasheninnikov, 60×, Sample 543A-7-4, 4-6 cm, (10) Neg. 02371, (11) Neg. 02386. 12-14. Paratrochamminoides semipellucidus Krasheninnikov, (12) $60 \times$, Sample 543A-7-4, 4-6 cm, Neg. 02388, (13, 14) $125 \times$, Sample 543A-7-2, 73-75 cm (13, Neg. 05330; 14, Neg. 05329). 15, 16. Paratrochamminoides vitreus Krasheninnikov, $80 \times$, (15) Sample 543A-7-1, 146-148 cm, Neg. 02392, (16) Neg. 02391. 17. Paratrochamminoides sp. $1,60 \times$, Sample 543A-6-1, 53-55 cm, Neg. 02394. 18. Paratrochamminoides sp. $2,60 \times$, Sample 543A-7-4, 4-6 cm, Neg. 02387 . 19. Trochamminoides cf. coronatus Brady, $60 \times$, Sample 543A-6-1, 53-55 cm, Neg. 02395. 20. Spiroplectammina dentata (Alth), 125 $\times$, Sample 543A-9,CC, Neg. 02415. 21-23. Spiroplectammina subhaeringensis (Grzybowski), 40×, Sample 543A-7-3, 73-75 cm, (21) Neg. 02365, (22) Neg. 02364, (23) ?microsphaeric form, Neg. 02366 . 

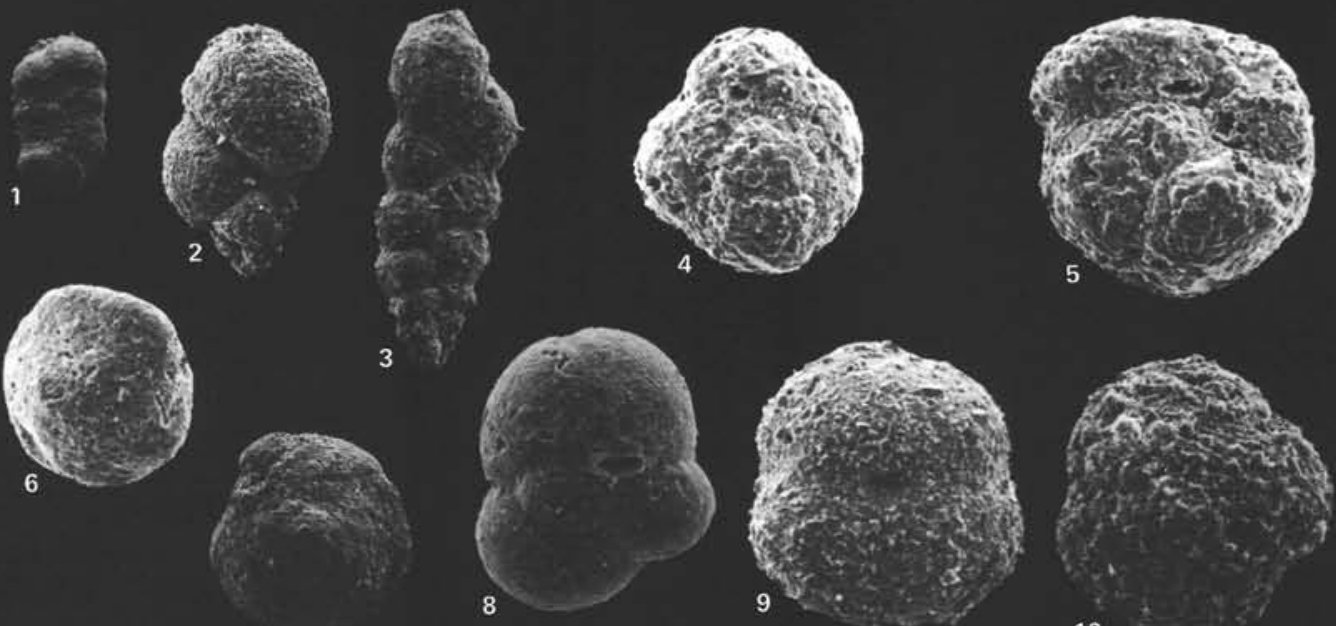

7
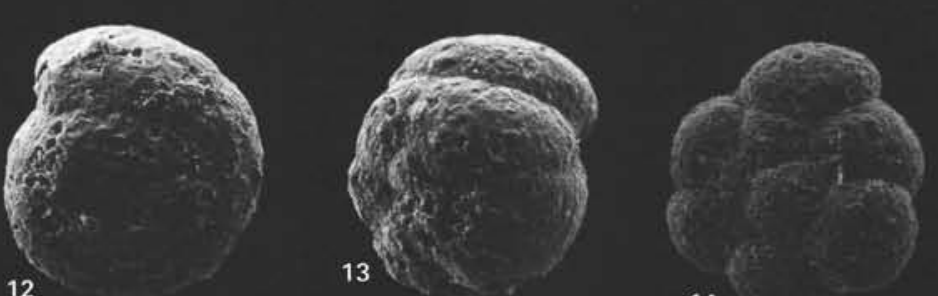

14
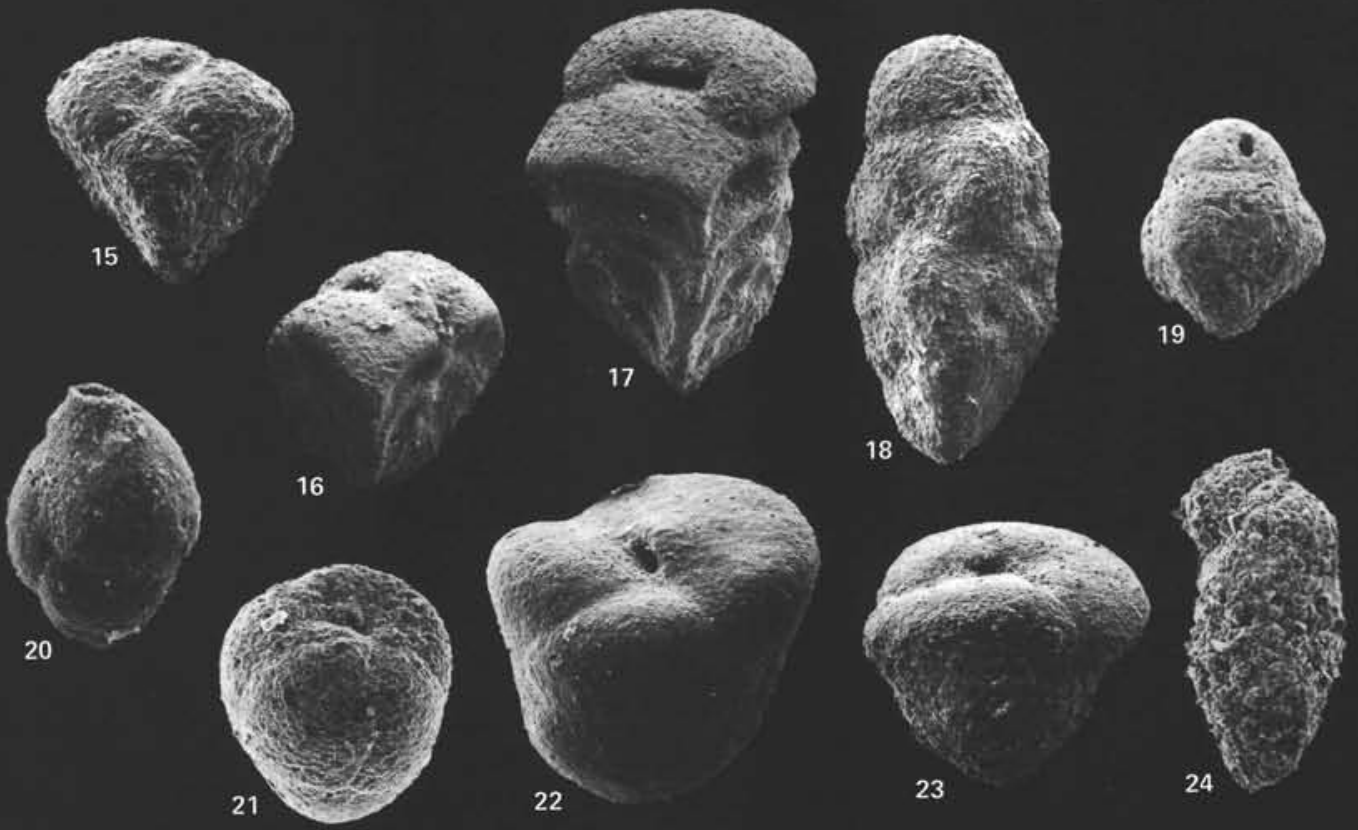

Plate 4. 1. Bolivinopsis parvissimus Krasheninnikov, $120 \times$, Sample 543A-9-1, 44-46 cm, Neg. 02358. 2. Pseudobolivina cuneata Krasheninnikov, $120 \times$, Sample 543A-9,CC (16-18 cm), Neg. 02413. 3. Pseudobolivina munda Krasheninnikov, 120 $\times$, Sample 543A-7,CC, Neg. 02361. 4. Plectorecurvoides parvus Krasheninnikov, $120 \times$, Sample 543A-7-4, 4-6 cm, Neg. 02405. 5. Plectorecurvoides rotundus Krasheninnikov, $120 \times$, Sample 543A-7-4, 4-6 cm, Neg. 02406. 6, 7. Plectorecurvoides sp., 120x, Sample 543A-7-4, 4-6 cm, (6) umbilical side, Neg. 02604, (7) spiral side, Neg. 02606. 8. Praecystammina globigerinaeformis Krasheninnikov, $120 \times$, Sample 543A-7-4, 4-6 cm, Neg. 02325. 9, 10. Trochammina ex gr. globigeriniformis (Parker and Jones), 120×, Sample 543A-9-1, 44-46 cm, (9) umbilical side, Neg. 02401, (10) spiral side, Neg. 02402. 11-13. Trochammina gyroidinaeformis Krasheninnikov $120 \times$, Sample 543A-7,CC, (11) umbilical side, Neg. 05289, (12) spiral side, Neg. 05295, (13) peripheral view, Neg. 05294. 14. Trochammina insueta Krasheninnikov, $120 \times$, Sample 543A-8-1, 143-145 cm, Neg. 05325. 15. Verneuilina cretacea Karrer, $80 \times$, Sample 543A-10-1, 25-27 cm, Neg. 05323. 16, 17. Gaudryina pyramidata Cushman, Sample 543A-9-1, 44-46 cm, 80×, (16) juvenile form, Neg. 02367, (17) 60×, adult form, Neg. 02368. 18. Pseudospiroplectinata compressciuscula (Chapman), $60 \times$, Sample 543A-10-1, 15-17 cm, Neg. 05291. 19. Tritaxia aspera (Cushman), 80×, Sample 543A-7-2, 73-75 cm, Neg. 02396. 20. Uvigerinammina jankoi Majzon, $240 \times$, Sample 543A-8,CC, Neg. 05296. 21. Arenobulimina orbignyi (Reuss), $80 \times$, Sample 543A-7-3, 73-75 $\mathrm{cm}$. 22. Dorothia crassa (Marsson), $80 \times$, Sample $543 \mathrm{~A}-10-1,25-27 \mathrm{~cm}$, Neg. 05292 . 23. Dorothia cf. oxycona (Reuss), $80 \times$, Sample $543 \mathrm{~A}-$ 10-1, 25-27 cm, Neg. 05290. 24. Plectina aff. conversa (Grzybowski), 120×, Sample 543A-9-1, 44-46 cm, Neg. 05301. 

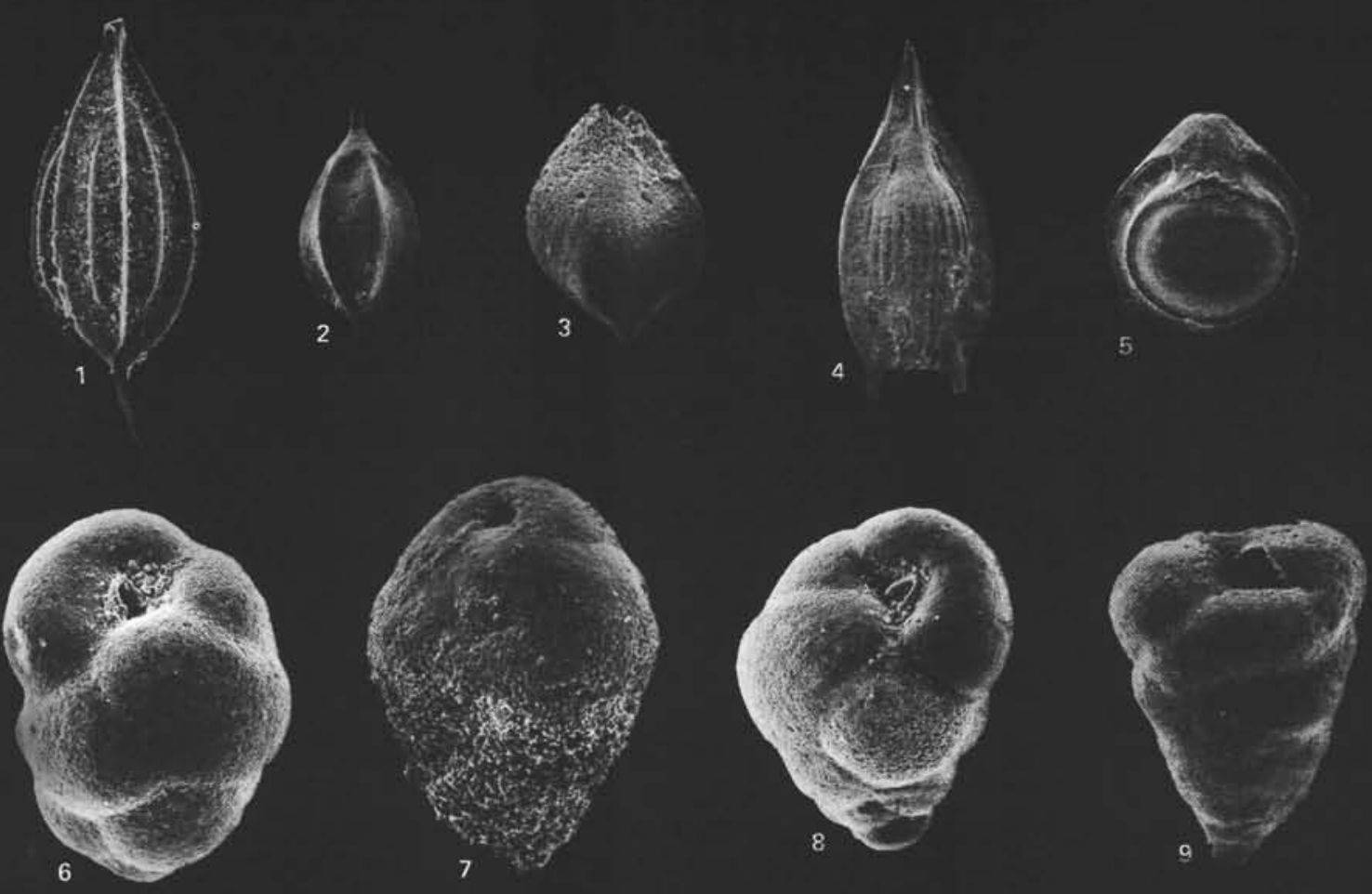
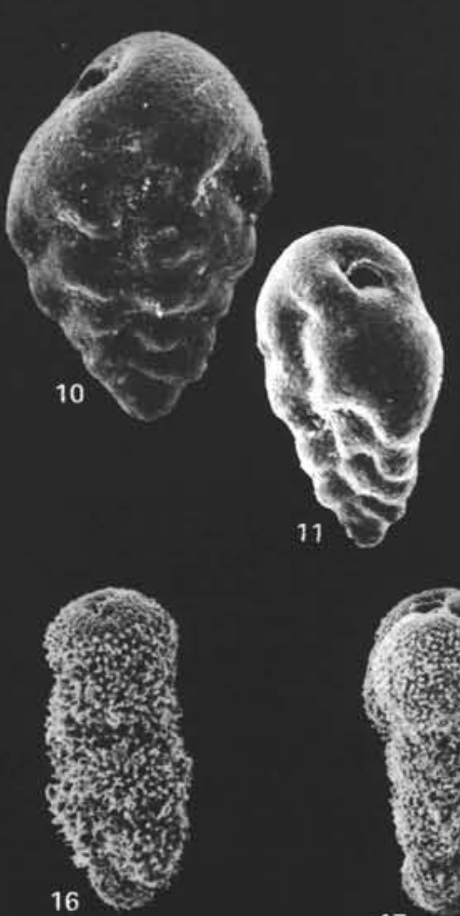
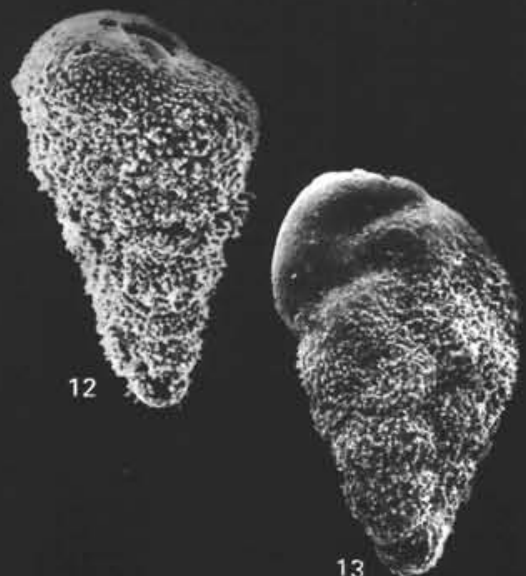

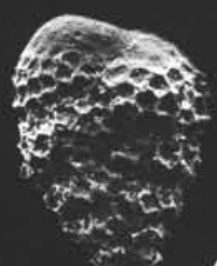

$14 \operatorname{lig}_{7}$

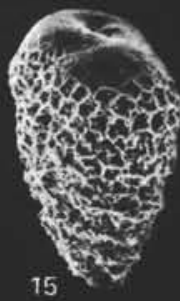

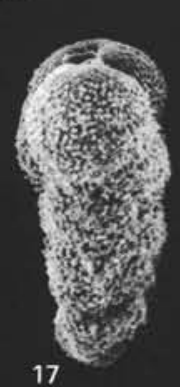
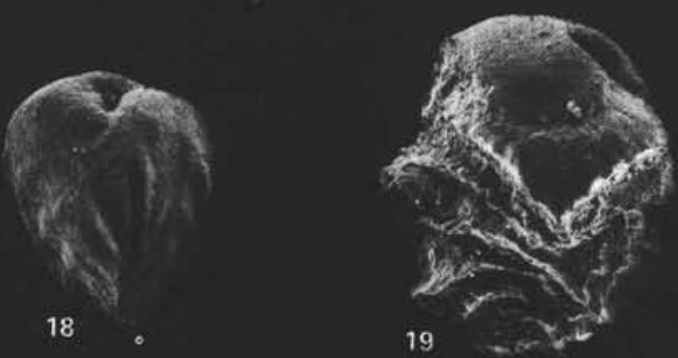

Plate 5. 1, 2. Lagena aff. sulcata (Walker and Jacob), 130×, (1) Sample 543A-7-2, 73-75 cm, Neg. 05639, (2) Sample 543A-7-2, 139-141 cm, Neg. 05274. 3. Guttulina cuspidata Cushman and Ozawa, $130 \times$, Sample 543A-9,CC, Neg. 05283. 4. Fissurina bicornis Neagu, $85 \times$, Sample 543A-7-3, 73-75 cm, Neg. 84575. 5. Fissurina orbignyana Sequenza, $85 \times$, Sample 543A-7-3, 7-8 cm, Neg. 05930. 6. Praebulimina cf. carseyae (Plummer), $130 \times$, Sample 543A-7-2, 139-141 cm, Neg. 06138. 7. Praebulimina cushmani (Sandidge), 130 $\times$, Sample 543A-10-1, 25$27 \mathrm{~cm}$, Neg. 05238. 8. Praebulimina reussi (Morrow), $215 \times$, Sample 543A-7-2, 73-75 cm, Neg. 06122. 9. Praebulimina sp., $215 \times$, Sample 543A-9,CC, Neg. 06157. 10, 11. Bolivina betieri Drooger, $215 \times$, Sample 543A-7-2, 73-75 cm, (10) Neg. 05648, (11) Neg. 06128. 12, 13. Bolivina sp., $215 \times$, (12) Sample 543A-7-2, 139-141 cm, Neg. 06142, (13) Sample 543A-7-2, 73-75 cm, Neg. 84626. 14, 15. Bolivina sp., 215×, (14) Sample 543A-7-2, 73-75 cm, Neg. 84629, (15) Sample 543A-7-2, 139-141 cm, Neg. 06147. 16, 17. Eouvigerina hispida Cushman, 215 $\times$, (16) Sample 543A-7-3, 7-8 cm, Neg. 06113, (17) Sample 543A-7-2, 139-141 cm, Neg. 06143. 18. Reussella cf. pseudospinulosa Troelsen, 130 , Sample 543A-7-3, 73-75 cm, Neg. 05235. 19. Reussella szajnochae (Grzybowski), 65 x, Sample 543A-7-2, 73-75 cm, Neg. 05641. 


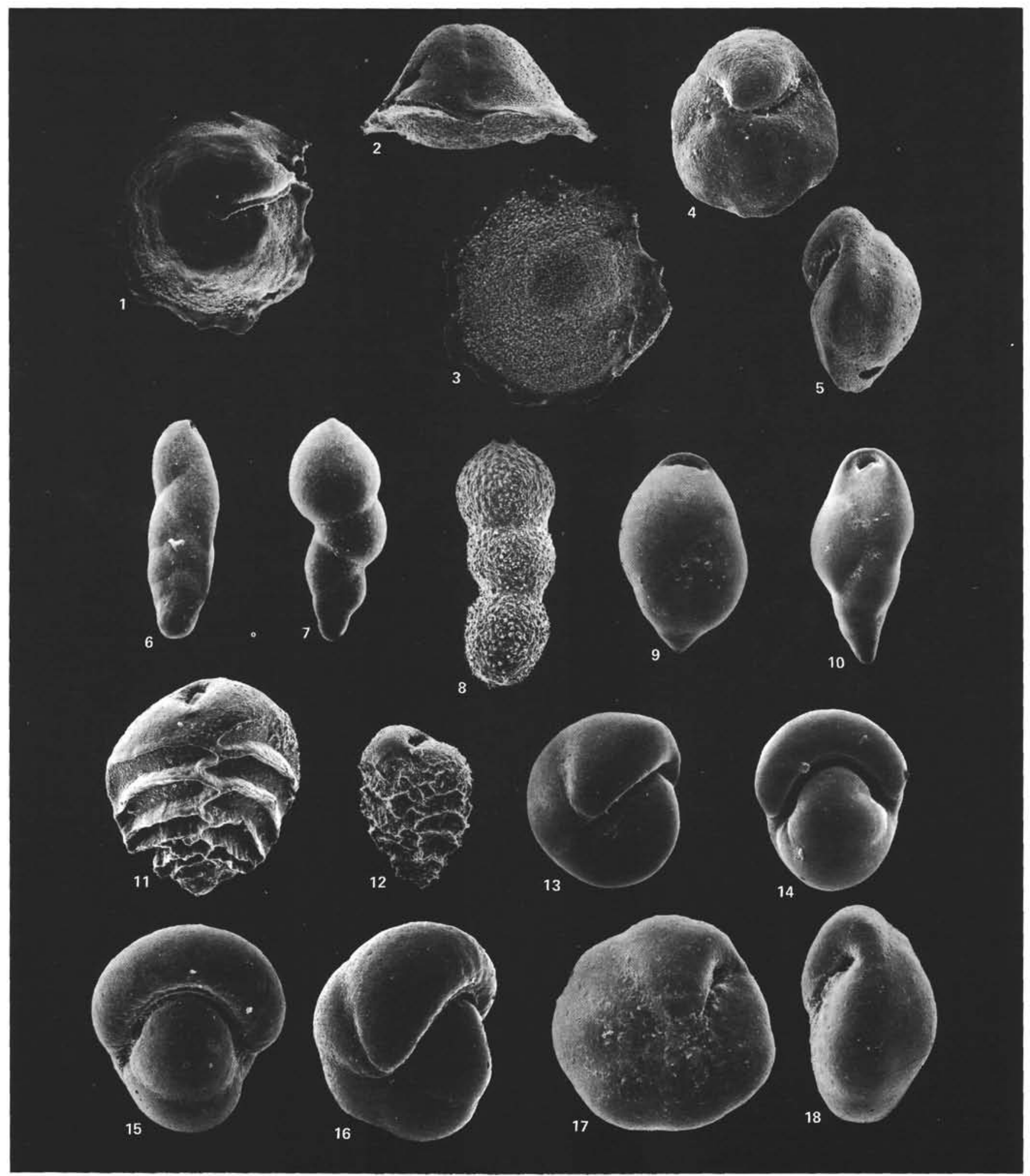

Plate 6. 1-3. Nuttallinella florealis (White), $60 \times$, Sample 543A-7-3, 73-75 cm, (1) umbilical side, Neg. 05268, (2) peripheral view, Neg. 05987,

(3) spiral side, Neg. 05650. 4, 5. Eponides cf. frankei Brotzen, 165 $\times$, Sample 543A-7-2, 139-141 cm, (4) umbilical side, Neg. 06102, (5) peripheral view, Neg. 05926. 6. Pleurostomella nitida Morrow, $125 \times$, Sample $543 \mathrm{~A}-7-2,73-75 \mathrm{~cm}$, Neg. 05962 . 7. Ellipsodimorphina subtuberosa Liebus, $125 \times$, Sample 543A-7-3, 73-75 cm, Neg. 05631. 8. Ellipsodimorphina sp., 85×, Sample 543A-7-2, 139-141 cm, Neg. 05275. 9. Ellipsopolymorphina velascoensis (Cushman), $60 \times$, Sample 543A-7-3, 73-75 cm, Neg. $05629 . \quad$ 10. Ellipsopolymorphina sp., 85 $\times$, Sample 543A7-2, 139-141 cm, Neg. 05636. 11. Aragonia ouezzanensis (Rey), $125 \times$, Sample 543A-7-3, 7-8 cm, Neg. 05253. 12. Aragonia velascoensis (Cushman), 125 $\times$, Sample 543A-7-3, 73-75 cm, Neg. 05230. 13, 14. Pullenia coryelli White, 125 $\times$, (13) Sample 543A-7-3, 73-75 cm, Neg. 05261, (14) peripheral view, Sample 543A-7-2, 73-75 cm, Neg. 84619. 15, 16. Pullenia cretacea Cushman $125 \times$, Sample 543A-7-2, 139-141 cm, (15) Neg. 06116, (16) Neg. 84587. 17, 18. Alabamina dorsoplana (Brotzen), 165 $\times$, Sample 543A-7-2, 139-141 cm, (17) umbilical side, Neg. 05924, (18) peripheral view, Neg. 05934. 

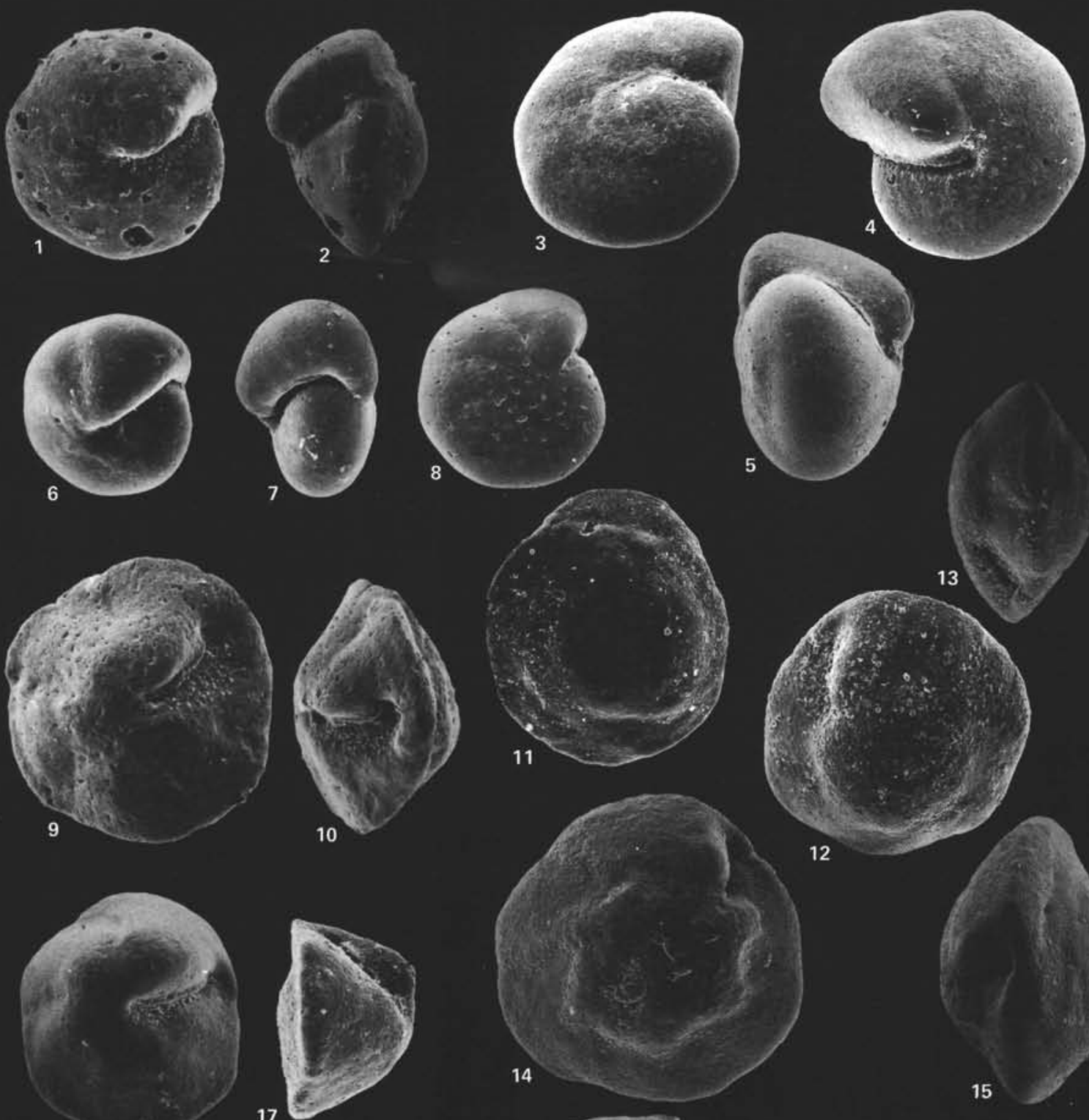

16

17
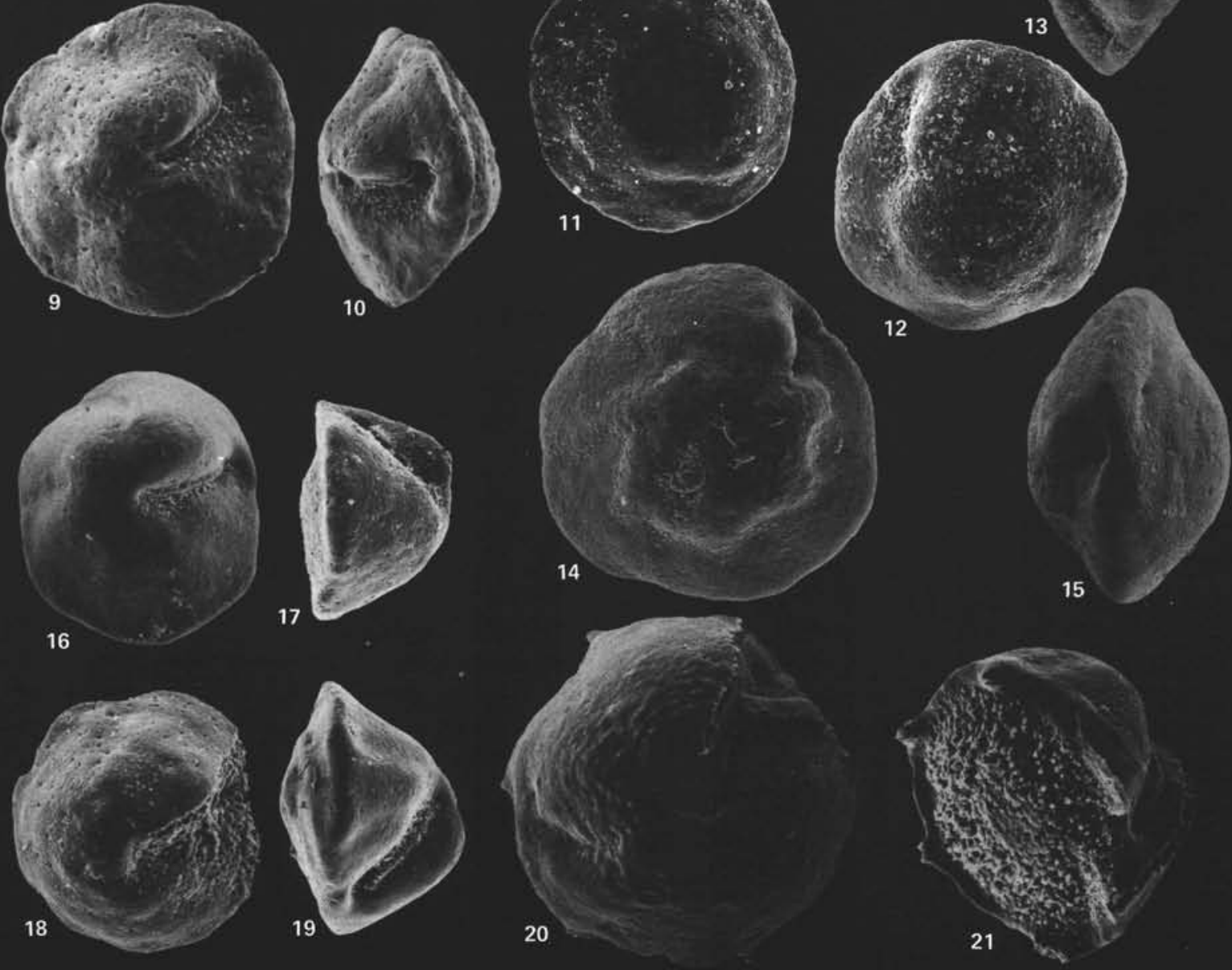

Plate 7. 1, 2. Gyroidina beisseli White, $125 \times$, Sample 543A-7-3, 7-8 cm, (1) umbilical side, Neg. 05670, (2) peripheral view, Neg. 05973 . 3-5. Gyroidina noda Belford, $125 \times$, Sample 543A-7-3, 73-75 cm, (3) spiral side, Neg. 05260, (4) umbilical side, Neg. 06107, (5) peripheral view, Neg. 05984. 6-8. Gyroidina sp., $125 \times$, (6) umbilical side, Sample 543A-7-2, 73-75 cm, Neg. 06126, (7) peripheral view, Sample 543A-7-3, 73-75 cm, Neg. 06108, (8) spiral side, Sample 543A-7-2, 73-75 cm, Neg. 06182. 9, 10. Osangularia cordieriana (d'Orbigny), 125x, Sample 543A-9,CC, (9) umbilical side, Neg. 05285, (10) peripheral view, Neg. 05959. 11-15. Osangularia whitei (Brotzen), 125 $\times$, (11) spiral side, Sample 543A-7-3, 7-8 cm, Neg. 05667, (12) umbilical side, Sample 543A-7-3, 4-9 cm, Neg. 06161, (13-15) Sample 543A-7-3, 7-8 cm (13, peripheral view, Neg. 05972; 14. umbilical side, Neg. 05666; 15, peripheral view, Neg. 05971. 16, 17. Globorotalites conicus (Carsey), 125 ×, Sample 543A-7-2, 139$141 \mathrm{~cm}$, (16) umbilical side, Neg. 05647, (17) peripheral view, Neg. 06111. 18, 19. Globorotalites multiseptus (Brotzen), 210×, Sample 543A-7-2, 139-141 cm, (18) umbilical side, Neg. 05664, (19) peripheral view, Neg. 06114. 20, 21. Globorotalites spineus (Cushman), 125 $\times$, Sample 543A-7-3, 73-75 cm, (20) umbilical side, Neg. 05267, (21) spiral side, Neg. 05270. 

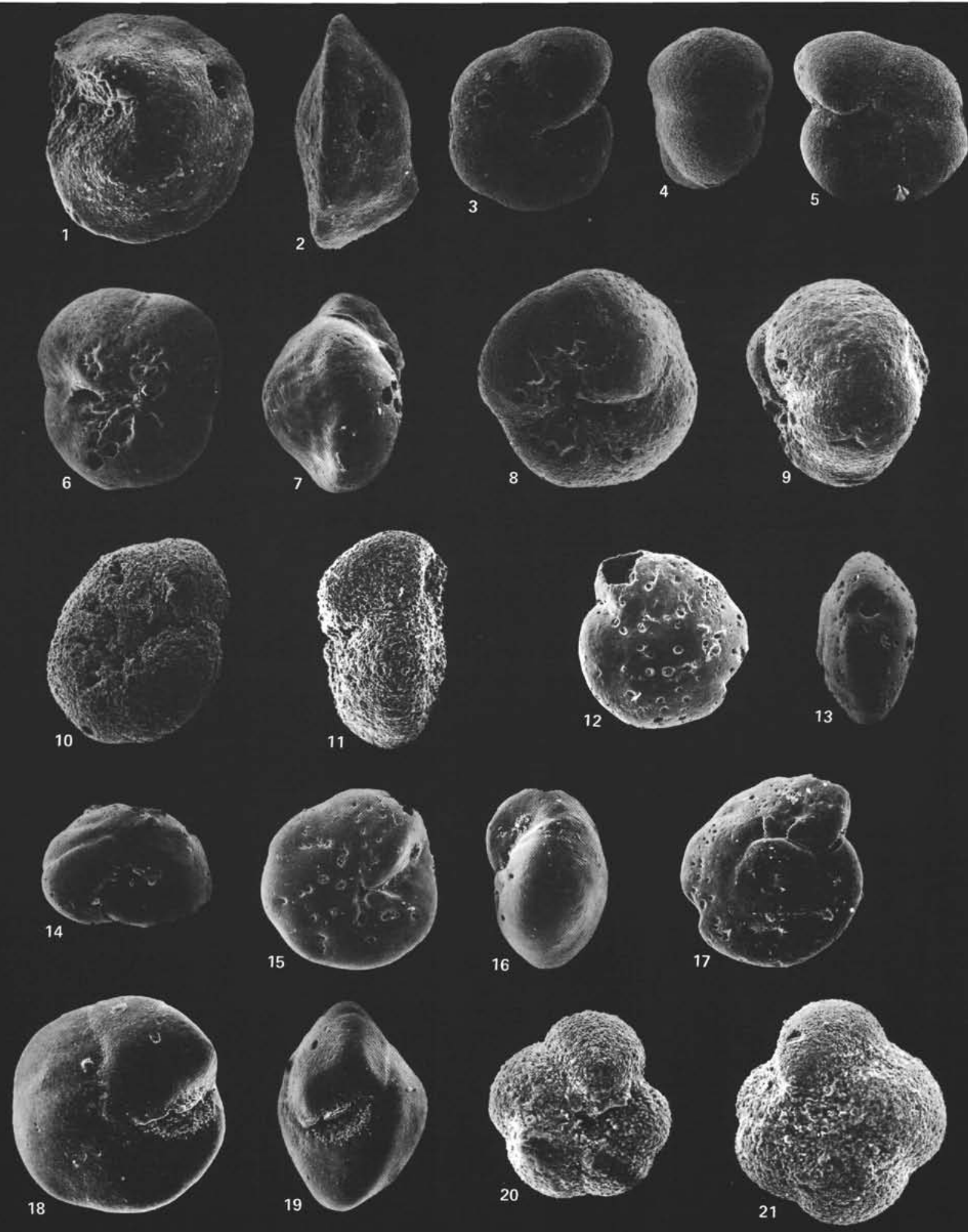

Plate 8. 1, 2. Globorotalites subconicus Morrow, 170×, Sample 543A-7-3, 73-75 cm, (1) umbilical side, Neg. 06100, (2) peripheral view, Neg. 05818. 3-5. Gavelinella brotzeni Said and Kenawy, 130×, Sample 543A-7-3, 7-8 cm, (3) umbilical side, Neg. 05671, (4) peripheral view, Neg. 05975, (5) spiral side, Neg. 05977. 6-9. Gavelinella cayeuxi mangyschlakensis (Vasilenko), 130× , (6, 7) Sample 543A-9, CC (6, umbilical side, Neg. 06013; 7, peripheral view, Neg. 06098), (8, 9) Sample 543A-10-1, 1-3 cm (8, umbilical side, Neg. 05916; 9, peripheral view, Neg. 06099). 10, 11. Gavelinella rubiginosa (Cushman), $130 \times$, Sample 543A-10-1, 15-17 cm, (10) umbilical side, Neg. 05242, (11) peripheral view, Neg. 06181. 12, 13, 17. Gavelinella cf. velascoensis (Cushman), 130×, Sample 543A-9,CC, (12) spiral side, Neg. 06110, (13) peripheral view, Neg. 05970, (17) umbilical side, Neg. 05661. 14-16. Gavelinella sp. ex gr. G. velascoensis (Cushman), (14) 170X, spiral side, Sample 543A-9,CC, Neg. 05662, (15, 16) $130 \times$, Sample 543A-7-3, 73-75 cm (15, umbilical side, Neg. 06015; 16, peripheral view, Neg. 06097). 18, 19. “Gavelinopsis" involutiformis Hofker, $130 \times$, Sample 543A-7-3, 73-75 cm, (18) umbilical side, Neg. 06153, (19) peripheral view, Neg. $06159.20,21$. Hedbergella holmdelensis Olsson, 210×, Sample 543A-10-1, 15-17 cm, (20) umbilical side, Neg. 06096, (21) spiral side, Neg. 06095. 